\title{
A New Electorate? Explaining the Party Preferences of Immigrant-Origin Voters at the 2017 Bundestag Election
}

\author{
Achim Goerres $^{1}$ (D), Sabrina Jasmin Mayer ${ }^{2 *}$ (D) and Dennis Christopher Spies ${ }^{3 \dagger}$ \\ ${ }^{1}$ University of Duisburg-Essen, Duisburg and Essen, Germany, ${ }^{2}$ University of Duisburg-Essen, Duisburg and Essen, and \\ DeZIM Institute, Berlin, Germany; and ${ }^{3}$ University of Düsseldorf, Düsseldorf, Germany \\ *Corresponding author. Email: sabrina.mayer@uni-due.de
}

(Received 16 January 2020; revised 16 February 2021; accepted 2 June 2021; first published online 5 October 2021)

\begin{abstract}
Immigrants now constitute a sizeable and rapidly growing group among many Western countries' electorates, but analyses of their party preferences remain limited. Theoretically, immigrants' party preferences might be explained with both standard electoral theories and immigrant-specific approaches. In this article, we rigorously test both perspectives against each other using the most recent data from Germany. Applying the Michigan model, with its three central explanatory variables - party identification, issue orientations and candidate evaluations - to the party preferences of immigrant-origin and native voters, we find that this standard model can explain both groups well. In contrast, we find no direct effects of the most prominent immigrant-specific variables, and neither do these meaningfully moderate the Michigan variables. However, we find strong formative effects on the presence of political attitudes and beliefs: immigrants with a longer time spent in Germany, a stronger German identity and less experience of discrimination report significantly fewer item non-responses for the Michigan model's main explanatory variables.
\end{abstract}

Keywords: immigrants; political preferences; voting behaviour; political integration; Germany; Michigan model

The integration of immigrants into host societies is at the heart of several debates in the social sciences, and an abundant literature has been written around immigrants' economic (Van Tubergen, Maas, and Flap 2004), cultural (for example, Wimmer and Soehl 2014) and social (for example, Ersanilli and Koopmans 2010) integration. In comparison, the political integration of immigrants has received scholarly attention only more recently (for a review, see Bird et al. 2011). Most of this attention has been devoted to the drivers of immigrants' formal (Fraga 2018; Oskooii 2018; Reichert 2013; Spies, Mayer, and Goerres 2020) or informal (Berger, Galonska, and Koopmans 2004; Jacobs and Tillie 2004) political participation, and to explanations of their politically relevant attitudes (De la Garza, Falcon, and Garcia 1996; Fennema and Tillie 1999; Heath et al. 2013). In contrast, comparatively few studies have addressed the drivers of immigrants' party preferences, especially outside the comparatively well-researched US context (De la Garza and Cortina 2007; De la Garza, Falcon, and Garcia 1996; Ramakrishnan and Espenshade 2001; Valdez 2011). With a few notable exceptions (Bergh and Bjørklund 2010; Dancygier and Saunders 2006; Sanders et al. 2014), scholarship on the party preferences of immigrant-origin voters is still in its infancy in Europe.

In this article, we analyse the party preferences of immigrant-origin voters, as compared with native voters, at the 2017 election to the German Bundestag. We define 'immigrant-origin voters'

\footnotetext{
${ }^{\dagger}$ Shortly after this article had been accepted, Prof Dennis C Spies passed away totally unexpected aged 40 (1981-2021). We are missing a dear and loyal friend and the best collaborator one might hope for. We will always remember him.

(c) The Author(s), 2021. Published by Cambridge University Press. This is an Open Access article, distributed under the terms of the Creative Commons Attribution-NonCommercial-NoDerivatives licence (http://creativecommons.org/licenses/by-nc-nd/4.0/), which permits non-commercial re-use, distribution, and reproduction in any medium, provided the original work is unaltered and is properly cited. The written permission of Cambridge University Press must be obtained for commercial re-use or in order to create a derivative work.
} 
as those who either immigrated themselves (first generation) or have at least one parent with this experience (second generation) but who have already acquired German citizenship and thereby also the right to vote. In Germany, around 6.3 million immigrant-origin voters were eligible to vote in the last federal election, representing around 10 per cent of the entire electorate. For international discussion, Germany is also an interesting case to study as it offers two very distinct groups of immigrant-origin voters: Turks as former guest workers and Russian-Germans as ethnic German 'late resettlers'. Also, Germany gives us the possibility of testing the theoretical assumptions that were mainly developed for the majoritarian US and UK systems in a multiparty system.

Theoretically, two perspectives can be distinguished when it comes to the analysis of immigrant-origin voters' party preferences. The first perspective is that these can be explained by the same theories that are used for native voters in standard electoral research. We account for this possibility by applying the Michigan model to both immigrant-origin and native voters, comparing the predictive power of its three central factors - party identification (that is, a longstanding psychological attachment to a political party) and short-term issue and candidate orientations - for both voter groups. Our overarching theoretical assumption is that differences in the party preferences of immigrant-origin and native voters can be explained by differences in the Michigan model's central explanatory variables - and thus by standard approaches of electoral research.

Following the second perspective, immigrant-origin voters' party preferences cannot be explained by standard electoral theories alone. Rather, we need additional immigrant-specific variables and approaches to fully understand them. We account for this perspective by adding three of the most widely discussed immigrant-specific factors to the Michigan model: length of stay in the host country, ethnic identity and discrimination experiences. All of these variables are prominently discussed in the integration literature, even if only few studies so far have related them to immigrants' party preferences. Thus, we theorize about these factors' direct, moderating and indirect effects on the Michigan model's three main explanatory variables. Our overall theoretical assumption is that more acculturated immigrant-origin voters will adapt their party preferences to those of native voters, while more recently arrived, culturally segregated and strongly discriminated immigrant-origin voters will show considerable differences in their party preferences that cannot be explained by standard approaches of electoral research.

Our representative survey data stem from the Immigrant German Election Survey (IMGES), a survey fielded after the federal election of September 2017, which includes both a standard electoral study and immigrant-specific factors, allowing for tests of influence between both. Using both multi-level regression models and path models of propensity to vote, we find sharp differences in the party support of immigrant-origin and native voters. At the same time, our findings suggest that the Michigan model can explain a large part of these differences, as both groups use party identification, as well as candidate and issue evaluations, when deciding their party preferences. In contrast, immigrant-specific factors have neither direct nor substantial moderating effects on the Michigan model's main explanatory variables. However, immigrants who have spent a longer time in Germany, have a stronger German identity and have less experience of discrimination report significantly fewer item non-responses for the Michigan model's main explanatory variables, that is, these immigrant-specific factors decide on whether immigrant-origin voters develop political attitudes and beliefs in the first place.

\section{Explaining Immigrants' Party Preferences with the Michigan Model}

The Michigan model - also known as the Ann Arbor model - is one of the most commonly used theoretical approaches for the explanation of individual voting behaviour in established democracies, and for Germany in particular (Krämer and Rattinger 1997; Neundorf and Adams 2018). It assumes that the majority of voters do not face a completely new and thus open decision- 
making situation before every election. Rather, they bring with them long-standing, affective, psychological linkages with a political party, that is, party identification. While party identification is itself acquired in primary socialization, it is seen as a stable construct that only changes with major life events. Once acquired, it then functions as a perceptual screen and, accordingly, directly affects voters' short-term attitudes towards candidates and their perceptions of issue competencies (Campbell et al. 1960, 133-8). According to the Michigan model, the voters' decision-making process is thus represented as a funnel of causality, the end point of which is the vote decision. Party identification, as a long-term factor, as well as the short-term factors of candidate and issue preferences, are upstream of this.

The Michigan model has been successfully applied to the study of native voters for decades (for an overview, see Johnston 2006). Thus, our baseline assumption is that the model can also be used to explain the party preferences of immigrant-origin voters (H1). Specifically, the model's short-term factors of candidate and issue orientations might be equally important for the vote decision of immigrant-origin and native voters alike. Of course, this does not mean that both groups like or dislike the same candidates, or regard the same issues as being important (Wüst 2004). However, we expect that candidate and issue preferences have the same explanatory power for both groups, as has been argued in studies from both the United States (Abrajano, Alvarez, and Nagler 2008; Barreto 2007) and the UK (Fisher et al. 2014; Heath et al. 2013).

In contrast, applying the Michigan model's central concept of party identification to the group of immigrant-origin voters seems more questionable. Party identification is defined as a relatively stable attachment to a political party, mainly acquired during primary socialization and, therefore, substantively transmitted within the family (Rekker et al. 2019). It is, therefore, unclear how firstgeneration immigrants (born and at least partly socialized abroad) and second-generation immigrants (having at least one parent not being born and socialized in the host society) might develop identification with the parties of their host country, or how they pass it on to their children. Consequently, the level of partisanship has been found to be much lower among US immigrant-origin than among native voters (Cain, Kiewiet, and Uhlaner 1991; Hajnal and Lee 2006; Uhlaner and Garcia 2005), and previous results from Germany also seem to resemble this pattern (Wüst 2004). However, some ethnically defined groups might also hold very strong party identities, as is reported, for example, in the UK (Heath et al. 2013, ch. 6) and for voters of Cuban origin in the United States (Bishin and Klofstad 2012). Thus, previous empirical results for the role of party identity for immigrant-origin voters' party preferences are ambiguous, and this pattern further seems to vary among distinct ethnic groups.

\section{Immigrant-Specific Approaches}

In contrast to the standard electoral theory perspective presented earlier, the second perspective highlights the role of immigrant-specific factors, that is, characteristics that are not relevant to native voters and are thus not accounted for by standard electoral theories (for a comparable approach on turnout, see Spies, Mayer, and Goerres 2020). In the following section, we focus on three of the most prominently discussed immigrant-specific factors: length of stay in the host country, ethnic identity and the role of discrimination experiences. ${ }^{1}$

\footnotetext{
${ }^{1}$ These three immigrant-specific approaches are surely not the only ones that are frequently discussed in research on immigrants' political integration. While we also test for ethnic group effects, we do not address language proficiency and ethnic network effects in our analyses. We have two main reasons for this. First, our sample of German immigrant-origin voters is not an ideal setting for testing for language proficiency, as nearly all respondents have a good or very good command of German. Keeping in mind that German citizenship is a necessary condition to participate in German federal elections (and, thus, also to be part of our sample), these figures come at little surprise. However, any estimates for language skills would, thus, have been extremely biased. Second, our decision to not include network effects is motivated by the lack of theoretical arguments relating these to immigrants' party preferences. At the same time, theoretically and empirically, ethnic network effects are often hard to separate from ethnic identity effects.
} 
Table 1. Summary of hypotheses

\begin{tabular}{|c|c|c|c|}
\hline H1 (Michigan model) & H2 (length of stay) & H3 (ethnic identity) & H4 (discrimination) \\
\hline \multirow{3}{*}{$\begin{array}{l}\text { H1: The standard Michigan } \\
\text { model can explain the party } \\
\text { preferences of native and } \\
\text { immigrant-origin voters } \\
\text { equally well. Its central } \\
\text { variables (party identification } \\
\text { and candidate and issue } \\
\text { evaluations) will have } \\
\text { comparable effects for native } \\
\text { and immigrant-origin voters. }\end{array}$} & $\begin{array}{l}\text { H2a: Length of stay in the } \\
\text { country of residence will } \\
\text { exert direct effects on } \\
\text { immigrants' party } \\
\text { preferences, even when } \\
\text { controlling for the } \\
\text { Michigan model's central } \\
\text { variables. }\end{array}$ & $\begin{array}{l}\text { H3a: Ethnic identity will } \\
\text { exert direct effects on } \\
\text { immigrants' party } \\
\text { preferences, even when } \\
\text { controlling for the } \\
\text { Michigan model's } \\
\text { central variables. }\end{array}$ & $\begin{array}{l}\text { H4a: Discrimination will } \\
\text { exert direct effects on } \\
\text { immigrants' party } \\
\text { preferences, even when } \\
\text { controlling for the } \\
\text { Michigan model's central } \\
\text { variables. }\end{array}$ \\
\hline & $\begin{array}{l}\text { H2b: Length of stay in the } \\
\text { country of residence will } \\
\text { moderate the effects of } \\
\text { the Michigan model's } \\
\text { central variables on } \\
\text { immigrants' party } \\
\text { preferences. }\end{array}$ & $\begin{array}{l}\text { H3b: Ethnic identity will } \\
\text { moderate the effects of } \\
\text { the Michigan model's } \\
\text { central variables on } \\
\text { immigrants' party } \\
\text { preferences. }\end{array}$ & $\begin{array}{l}\text { H4b: Discrimination will } \\
\text { moderate the effects of } \\
\text { the Michigan model's } \\
\text { central variables on } \\
\text { immigrants' party } \\
\text { preferences. }\end{array}$ \\
\hline & $\begin{array}{l}\text { H2c: Length of stay in the } \\
\text { country of residence will } \\
\text { exert formative effects on } \\
\text { the Michigan model's } \\
\text { central variables. }\end{array}$ & $\begin{array}{l}\text { H3c: Ethnic identity will } \\
\text { exert formative effects } \\
\text { on the Michigan } \\
\text { model's central } \\
\text { variables. }\end{array}$ & $\begin{array}{l}\text { H4c: Discrimination will } \\
\text { exert formative effects on } \\
\text { the Michigan model's } \\
\text { central variables. }\end{array}$ \\
\hline
\end{tabular}

By including these variables in the Michigan model, we argue that they may affect party preferences in three possible ways. First, they may have their own statistically significant, direct relationship with party preferences - irrespective of the Michigan model core variables. Second, they may moderate the effects of party identification, candidate choice and issue orientations on immigrant-origin voters' party preferences. Third, immigrant-specific variables might already have a formative effect on the presence of political attitudes and beliefs at the beginning of the Michigan model's funnel of causality by determining whether immigrant-origin voters are able to answer the question of whether they identify with a party or can report meaningful attitudes towards both candidates and issues. Empirically, variation in item non-response might indicate such formative effects. In the next section, we develop our arguments for the effects of length of stay, ethnic identity and discrimination, and structure our expectations between their direct, moderating and formative effects. Table 1 summarizes our theoretical expectations.

\section{Length of Stay}

The possibly most prominent immigrant-specific variable is length of stay in the country of residence. Length of stay is often equated with immigrant generation as well as political socialization, assuming that second-generation immigrants (being, by definition, born and thus politically socialized in their country of residence) have also spent more years in their country of residence than their first-generation parents. While this might surely be a vague assumption for many cases, for the analysis of immigrants' vote choice, it seems more reasonable, as only adult citizens are allowed to vote. Thus, second-generation immigrant-origin voters would at least have spent their entire youth (18 years in the German context) in the country of residence. Therefore, length of stay can indeed be expected to be correlated with immigrant generation, as well as with the country of political socialization, allowing us to also apply arguments developed for these later variables for our own theoretical model.

Summarizing the direct effects of length of stay $(\mathrm{H} 2 \mathrm{a})$, the majority of studies report that there is such an effect on vote choice but, at the same time, state that 'there is relatively little theory' to support it (DeSipio and Uhlaner 2007, 196). In the United States, several studies address how the vote choice of Latino voters is affected by their time spent in the country, with the voting patterns of Mexican-origin voters being at the centre of such analyses (Abrajano, Alvarez, and Nagler 
2008; De la Garza, Falcon, and Garcia 1996; DeSipio and Uhlaner 2007). For Europe, recent findings from the UK show not only that immigrant-origin voters held a strong preference for the Labour Party in the 2010 election, but that this support pattern was further linked to their time spent in Britain (Heath et al. 2013, 117). For Germany, the two major groups of immigrant-origin voters also show traditionally high support patterns: for the Social Democrats among Turkish-origin voters; and for the Christian Democrats among post-Soviet-origin voters (Wüst 2004). In summary, we can assume a strong direct effect of length of stay in the country of residence on immigrant-origin voters' party preferences, with its pattern potentially varying between immigrant groups.

Turning to the moderating effects of length of stay (H2b), it is a common assumption of integration research that immigrants tend to become more similar to native citizens in terms of variables such as income (Massey 1986), formal education (Rumbaut 2005) and values (De la Garza, Falcon, and Garcia 1996) the longer they live in the host society. Immigrants tend to assimilate. The equivalent assumption for their voting preferences is that they might also become more similar to native voters the longer they stay in the country of residence, especially as variables such as income, education and values are known to exert a strong influence on party preference. As far as the three basic variables of the Michigan model are concerned, previous studies have mainly addressed a moderating effect of length of stay on party identification. For the United States, DeSipio and Uhlaner $(2007,191)$ report that party identification had a much greater impact on the vote choices of the third and later generations of Mexican-origin voters in the 2004 presidential election. Following these authors, we can thus assume that greater knowledge and experience of the host society's political system - whether regarding party identification or candidate or issue orientations - also increase the effect of these variables on vote choice with greater length of time spent in the country of residence. At the same time, we assume that length of stay might be of special importance for the effect of party identification, as party identification needs considerable time to develop. In addition, we expect a more limited moderating effect of length of stay on candidate and issue orientations, the two shorter-term factors of the Michigan model, which should be more easily accessible for recently arrived immigrant voters.

Finally, and upstream from its direct and moderating effects, length of stay might also exercise a formative effect on the three variables of the Michigan model by increasing immigrants' affiliation to parties, as well as broadening their knowledge about candidates and issues (H2c). The longer immigrants live in the host country, the more familiar they become with the political system (for example, DeSipio and Uhlaner 2007); thus, length of stay might affect the formation of political attitudes and party attachments prior to the mechanisms that lead to the formation of party preferences as a form of cognitive and affective politicization (Reichert 2013). Empirically, the level of knowledge and meaningful attitudes might be captured by the amount of item nonresponse: immigrants who have spent a longer time in their country of residence might report significantly fewer item non-responses on the Michigan model's core variables than those who have arrived more recently. From this perspective, 'Don't know' answers are valid responses from those who do not possess such attitudes and attachments, and are therefore not able to react to the stimulus of the question (Kroh 2006).

To our knowledge, only a few studies so far have used this perspective for the analysis of migrants' political behaviour. Wals (2013) finds that the ability of Mexican-origin voters to place themselves on the left-right political scale in the United States is also related to the years they have spent in the country. Studies from Germany (Kroh and Tucci 2010) and Norway (Bergh and Bjørklund 2010) show that the likelihood of having acquired party identification increases substantially with each year in the host country. Next to party identification, we thus hypothesize that a comparable effect is at work for issue and candidate orientations: the longer the time spent in the country of residence, the more immigrant-origin voters might develop and report meaningful attitudes and preferences about the Michigan model's core variables. 


\section{Ethnic Identity}

Besides length of stay in the country of destination, several studies stress the importance of immigrants' ethnic identity for their vote choice (for example, Bergh and Bjørklund 2010; Dancygier and Saunders 2006; Dawson 1994; Goerres, Mayer, and Spies, 2020; Teney et al. 2010). According to the social identity approach (Tajfel and Turner 1979), social categorizations such as ethnicity are cognitive instruments that are used to systematically order the social environment into 'in-groups' and 'out-groups'. Whatever formal or informal groups individuals associate with constitute their in-group; an out-group includes individuals who do not share the same salient social traits. For immigrant-origin voters, the most relevant self-assigned categories are expected to be 'ethnic identity' and 'national identity' (of their host society because immigrant-origin voters have, by definition, been naturalized). It is a well-known fact in research on cultural acculturation that people may simultaneously hold several identities and activate them occasionally depending on the context (Berry 1984). Ideally, immigrants combine their ethnic and national identity in the form of a 'dual identity' (Simon, Reichert, and Grabow 2013), using their unique situation to build on the resources provided by both cultures. However, identities might also come into conflict with each other, especially if a strong identification with the ethnic/migrant group prevents at least a minimal identification with the host society (Diehl and Blohm 2001; see also Hamidou-Schmidt and Mayer 2021).

Starting with the direct effects of ethnic identity on immigrant-origins' vote choice (H3a), it is important to note that being part of a social category or group by birth - whether defined by ethnicity, race or nationality - does not in itself shape political perceptions. Only when this membership becomes part of one's social identity does it substantially affect political attitudes and behaviour through the process of depersonalization. Immigrants who identify closely with the ethnically defined in-group tend to see their own well-being as closely related to that of the group. This idea of a 'linked fate' (Dawson 1994) might then exert its influence via ethnic-group voting: voting for a party that is perceived to represent the interests of the in-group best. Examples of ethnic-group voting are manifold. For immigrant-origin voters, the strong support of Cuban-origin voters for the US Republicans (Bishin and Klofstad 2012), that of Commonwealth-origin voters for the British Labour Party (Heath et al. 2013) and that of Turkish-origin voters for the German Social Democrats (Wüst 2004) are only some examples. While detailed empirical analysis of the patterns behind these strong affiliations are rare (but see Bergh and Bjørklund 2010), from the perspective of ethnic-group voting, they occur because immigrants vote for the party they perceive as representing the interests of their in-group. From this perspective, ethnic identity might bypass both party identification and candidate and issue perceptions.

However, we can also expect a moderating effect of ethnic identity on the Michigan model's core variables (H3b). Previous studies of Latino voters in the United States (Barreto 2007; Hajnal and Lee 2006; Uhlaner and Garcia 2005) argued that the perception of a linked fate fosters the occurrence of party identification and thus positively affects its weight for vote choice. For Norway, Bergh and Bjørklund (2010) analysed the strong support for left-wing parties among non-Western immigrant-origin voters. Distinguishing between more ideological or rational voting considerations, based on individual self-interest, and those stemming from group membership, the authors conclude that voters are largely motivated by the latter - even if that means that they then support parties that do not match their own ideology or individual issue preferences. A comparable effect is described by Heath et al. (2013), who explain the greater loyalty of minority ethnic voters to the Labour Party in the 2010 British election. The moderating effects of the ethnic identity of political candidates are also prominently discussed. Focusing on Latino voters in the United States, Barreto (2007) concludes that their turnout and vote decisions are strongly affected by the existence of co-ethnic candidates - support patterns that are also relevant if voters and candidates 'have only the term Latino in common' (Barreto 2007, 427). For strong 
ethnic identifiers, it can be reasonably assumed that these support patterns are even more pronounced (Sanchez 2006; Stokes 2003). At the same time, immigrant-origin voters who are predominantly motivated by their ethnic identity might easily downplay or completely ignore their rational self-interest when casting their votes, thereby diminishing the role of candidate and especially issue effects within the Michigan model.

Theoretical assumptions about the formative effects of ethnic identity on the three Michigan model variables (H3c) are ambiguous. We might assume that strong ethnic identifiers use their ethnically defined networks to gather knowledge on parties, candidates and issues (Fennema and Tillie 1999; Tillie 2004); however, if their ethnic identity alone is relevant for their vote choice, there is little need for them to gather such knowledge. Rather, ethnic identity might function as an information shortcut, making more demanding policy or candidate evaluations irrelevant (Dancygier and Saunders 2006, 973). Therefore, we would expect strong ethnic identifiers to have less knowledge about the Michigan model's core variables (see Uhlaner and Garcia 2005). In addition, studies of ethnic network effects point to the potentially segregated environment of strong ethnic identifiers, providing strong bonding capital to the ethnic community while, at the same time, limiting bridging capital to the host society (Tillie 2004). For Germany, Berger, Galonska and Koopmans (2004) conclude that for various immigrant groups in Berlin, being rooted in ethnic communities has politically disabling effects and leads to less interest in German politics (see also Diehl and Blohm 2001, 414). Culturally and socially segregated, such voters might even feel alienated from German politics and thus not hold preferences regarding the Michigan model's core variables - a pattern frequently reported for African Americans (Citrin et al. 1975) and Latinos (Pantoja and Segura 2003) in the United States.

\section{Discrimination}

Finally, the third immigrant-specific approach highlights the role of discrimination experiences in the country of destination. Broadly defined, discrimination entails drawing a distinction between judgements or actions in favour of or against a person or group, based on any possible characteristic (Blank, Dabady, and Citro 2004; Krieger 1999). While discrimination experiences are certainly not restricted to immigrant-origin voters, discrimination based on ethnicity, race or immigrant status can be expected to play a prominent role in them (Schildkraut 2005). Furthermore, discrimination might come in several sub-forms, depending on whether it is experienced personally or experienced as discrimination against the in-group (Sanders et al. 2014). It might also depend on the person or institution doing the discriminating (Oskooii 2018). While discrimination is seen as an important variable in the literature on immigrants' political behaviour, previous studies have mainly dealt with its hindering or favouring effects on political participation. Thus, we will focus on the arguments stemming from the participation literature and relate them to the few previous studies that relate discrimination to vote choice.

There are only limited arguments about the potential direct $(\mathrm{H} 3 \mathrm{a})$ and moderating effects (H3b) of discrimination on party preferences. Simon, Reichert and Grabow (2013) describe how discriminated people engage less in formal forms of political participation, including support for political radicalism, but more in informal or illegal forms. We might thus expect that discrimination leads to a more radical political orientation, including support for more radical parties. As to the effects of discrimination on mainstream party support, Sanders et al. (2014) analyse the support patterns of immigrant-origin voters in the 2010 UK election. The authors report that group-based discrimination increases the probability of voting for Labour (because the party has historically cared most about underprivileged minorities), whereas personal discrimination is negatively related to Labour support (because Labour was the incumbent party and was held responsible for not preventing discrimination). The former interpretation might support a moderating effect of discrimination on party identification, and the latter might support increased issue or performance voting. In a related study on candidate support in the same 
election, Fisher et al. $(2014,880)$ argue that 'perceived racial discrimination might also be associated with greater support for co-ethnic or non-white candidates', especially among strong ethnic identifiers. However, they find no support for this assumption in their empirical analyses.

Ending with the potential formative effects of discrimination on the presence of political attitudes and beliefs $(\mathrm{H} 3 \mathrm{c})$, the argument depends very much on if we assume a positive or depressing effect of discrimination on political participation. On the one hand, a substantial body of public health research shows that exposure to discrimination is associated with feelings of inferiority, powerlessness and depression (Oskooii 2018; Schildkraut 2005). Such negative feelings are also prominently discussed in the literature on political alienation (for a recent review, see Fox 2020) and have been shown to reduce the likelihood of voting in general (Ojeda and Pacheco 2017), as well as the political participation of immigrants specifically (Pantoja and Segura 2003). Thus, we can assume that experiences of discrimination might lead immigrants to be alienated from the host country society, reducing their motivation to participate in political life and thereby also reducing their probability of gathering information about parties, candidates and issues (Saggar 2000; Simon, Reichert, and Grabow 2013). On the other hand, there is also convincing empirical evidence that discrimination might increase political participation, especially the participation of minority ethnic groups. If one traces discrimination experiences not back to oneself as an individual, but back to one's membership in a group, feelings of shared identity, group attachment, linked fate or group consciousness can be strengthened (Sanchez 2006; Stokes 2003). As discussed in the ethnic identity section, such a sense of connectedness might well encourage group members to become politically cohesive and active, with the reaction of Latinos to anti-immigrant initiatives (Barreto and Woods 2005; Pérez 2015; Ramírez 2013) and the strong support for Barack Obama by alienated racial minorities in general (Southwell 2012) being two recent examples.

\section{Data and Methods}

In order to analyse the drivers of immigrant-origin voters' party preferences, we relied on the most recent post-election survey data gathered from the German general election of September 2017. We combined data from the IMGES for immigrant-origin voters (Goerres, Spies, and Mayer 2020) with the German Longitudinal Election Study (GLES) for native voters (Roßteutscher et al. 2017), from which we exclude all immigrant-origin voters. The IMGES was especially designed to be comparable with the GLES in terms of field time, survey mode and questionnaire design, allowing for comparisons between the two samples. In both studies, response rates were similar at 28-29 per cent. Most importantly, the operationalization of our dependent and independent variables does not differ between the two surveys. The IMGES targets the two biggest groups of immigrants in Germany: eligible German voters aged 18+ with a background from Turkey or from the former Soviet Union and its successor states. The GLES has a native-voter-only sample size of 1,735 ; the IMGES has a sample size of 947 . We weighted our data with a post-stratification weight that takes into account differences in selection probability due to sample design and non-response.

\section{Operationalization of Dependent and Independent Variables}

For the dependent variable, we used propensity to vote (PTV $)^{2}$ for the parties that entered the Bundestag: the Christian Democratic Party (CDU, in all states but Bavaria)/the Christian

\footnotetext{
${ }^{2}$ For a multiparty system such as Germany's, the use of PTV has two main advantages compared to nominal-scale variables of vote choice First, it is possible to distinguish more clearly between the set of choices voters choose from and their actual voting decisions (van der Eijk et al. 2006). While both are largely the same in two-party systems, in multiparty systems, where voters have high utilities for several parties, using PTV items provides additional information, allowing us to measure preferences for several parties in a non-ipsative way (choosing one alternative does not exclude others). Second, PTV lessens the effects of social desirability (Johann et al. 2016).
} 
Social Party (CSU, only in Bavaria), the Social Democratic Party (SPD), the Free Democratic Party (FDP), the Green Party, the Left Party and the Alternative for Germany (AfD). For the operationalization of PTV, we used the following item: 'We have a number of political parties in Germany, each of which would like to get your vote. How probable is it that you will ever vote for the following parties? Please answer on a scale where 0 means "not at all probable" and 10 means "very probable".' Three categories for item non-response were offered: 'I don't know this party', 'Don't know' and 'Refused', which we all coded as missing values. Regarding the three core variables of the Michigan model, we operationalized party identification by using the established German standard item: 'Many people in the Federal Republic lean towards a particular party for a long time, although they may occasionally vote for a different party. How about you?'3 Apart from the major parties in Germany and the non-response categories 'Don't know' and 'Refused', the option 'None' was also offered as an answer category, allowing us to distinguish between those that do not have a party identification and those that are not able to answer the question as they do not have an opinion.

Candidate evaluations were measured by feeling thermometers for the leading politician of the party group, that is, for Angela Merkel (CDU/CSU), Martin Schulz (SPD), Christian Lindner (FDP), Cem Özdemir (Greens), Sahra Wagenknecht (Left) and Alexander Gauland (AfD). Respondents were asked to rate the politicians on an 11-point rating scale, ranging from -5 ('I have a very negative opinion of the politician') to +5 ('I have a very positive opinion of the politician'). Non-response categories included 'Don't know this politician', 'Don't know' and 'Refused', which we all coded as missing values. For issue competence perceptions, respondents were first asked an open question: 'What is currently the most/second most important political problem in Germany?' Afterwards, they were asked: 'And which party, according to you, is most capable of solving <Text of the most/second most important problem>?' Besides 'Don't know' and 'Refused', the option 'None' was also offered for these questions to distinguish between no opinion and no issue competency, with only the first coded as a missing value. Responses were scored from 0 if the party was never mentioned, to 2 if the party was mentioned for both the most and the second most important problem.

The three immigrant-specific variables are only included in the IMGES survey, not in the GLES. For the length of time spent in Germany, we divided the time elapsed since respondents immigrated to Germany in years by their age in years (for a similar approach, see Bergh and Bjørklund 2010). The resulting ratio ranged from 0.01 (for recently arrived first-generation immigrants) to 1 (for second-generation immigrants who have lived all their life in Germany). Ethnic identity was measured on a five-point scale by asking respondents if they felt they were a member of one of the most common ethnic groups in their home country, ranging from 1 ('does not apply at all') to 5 ('totally applies'). We asked Germans of Turkish descent if they felt 'Turkish' or 'Kurdish', and Germans of post-Soviet descent if they felt 'Russian-German' or 'Russian'. We took the highest value over all groups for every respondent. For discrimination, we rely on groupbased discrimination as a filter question for individual experiences. We first asked respondents if they would describe themselves as being a member of a group that is discriminated against in Germany (yes/no). We then asked why the group is discriminated against, for example, because of their ethnic origin, language, gender, disability or religion. Those that named ethnic origin, language and/or religion as reasons were then asked how often they had experienced discrimination in five domains within the last five years, such as at the workplace or by the police, on a three-point rating scale (often, sometimes, rarely). We calculated the mean frequency of

\footnotetext{
${ }^{3}$ This item has been established since the 1970s for the measurement of party identification in Germany and is also used by GLES, allowing us comparisons between native and immigrant-origin voters. Compared to the wordings used in the United States and UK, it is more complex, as it includes an introduction. However, the cue 'lean towards' is weaker than the United States/UK question, thus also capturing sympathizers. For international comparisons, differences in question wordings could also affect the results, and we would suppose that non-response would in general be lower in Germany, as the 'lean towards' stage is easier to reach than the think of yourself part.
} 
discrimination over all five domains, resulting in a variable with values from 1 (seldom discrimination) to 3 (very frequent discrimination). All respondents who did not describe themselves as being part of a discriminated group were coded as 0 . Controls were included for age (in years), gender (reference: female), political interest ('How strongly are you interested in politics?'; range: 1 ['not at all'] to 5 ['very strongly']) and education ('low' for less than 10 years, 'medium' for 10 to 11 years, and 'high' for university entrance exam, the German Abitur). As 39 per cent of the IMGES participants went to school in their country of origin, we asked for the number of years they had attended school in order to make this measure comparable with the German system. Accordingly, respondents with less than 10 years of schooling were coded as 1,10 to 11 years (and no university studies) were coded as 2 and more than 11 years were coded as 3 . Furthermore, we controlled for the immigrant groups $(1=$ Turkish descent; $2=$ post-Soviet descent $)$. All continuous variables were coded to range from 0 to 1 to allow for the comparison of magnitudes of effect sizes across variables.

\section{Analytical Strategy and Approach to Missing Values}

Our analytical strategy consisted of two steps, each associated with a particular method. First, we analysed the Michigan model's explanatory power for both immigrant-origin and native voters (H1), also testing for potential direct $(\mathrm{H} 2 \mathrm{a}, \mathrm{H} 3 \mathrm{a}, \mathrm{H} 4 \mathrm{a})$ and moderating effects of the immigrantspecific variables (H2b, H3b, H4b). We did this by applying multi-level models to PTV. For these models, we transformed our data to the long format, with six rows of party utilities per respondent. The unit for analysis is therefore no longer the respondent, but the respondent's evaluation of a single party (see van der Eijk et al. 2006). The stacked data format increases the sample size by a factor of six. We account for the clustering on the level of the individuals by estimating multi-level linear regression models with random intercepts and robust standard errors, with PTV as firstlevel and individuals as second-level units.

Second, by focusing on the potential formative effects of the immigrant-specific variables $(\mathrm{H} 2 \mathrm{c}, \mathrm{H} 3 \mathrm{c}, \mathrm{H} 4 \mathrm{c})$, we estimated path models with robust standard errors. Here, our interest is whether the immigrant-specific variables already determine whether immigrant-origin voters express a party identification or report meaningful attitudes towards candidates and issues. Certain levels of item non-response are common in most surveys and are thus often part of research (for example, Berinsky 2008; Tourangeau, Rips, and Rasinski 2012). In general, two reasons for item non-response are discussed (Riphahn and Serfling 2005; Tourangeau, Rips, and Rasinski 2012): either respondents do not want to provide answers, for example, due to the sensitive nature of questions (Tourangeau and Yan 2007); or respondents are not able to provide answers because they do not understand the question, are not able to recall the content it taps (for example, vote choice several years ago) or honestly do not have an opinion because they never/rarely dealt with the question's topic (Kroh 2006; Riphahn and Serfling 2005).

Explicitly modelling these patterns of missingness, we assumed that item non-responses mainly represented the valid answers of those without political attitudes or party attachments (Rubin, Stern, and Vehovar 1995), and thus assume that they are 'valid non-responses': respondents do not indicate a directional attitude because they genuinely do not have one. We used item non-response dummies for all three Michigan factors, coding item non-responses such as 'Don't know' and 'Refused' as 1, and all other answers as 0 . Thus, we are able to distinguish between no opinion, that is, those answering 'Don't know' or who refuse to answer, and those expressing negative opinions, that is, that they do not identify with a party, do not judge one party as being competent to solve an issue or do not like a politician or are not likely to vote for a party.

As reported in Table 2, the proportions of missing values on propensities to vote, party identification and candidate evaluations are quite high in some of our sample(s). The proportion is always lowest for native voters and almost always highest for Germans of (post-)Soviet descent. Evaluations of smaller parties tend to yield higher proportions than these of bigger parties. 
Table 2. Shares of missing values in percentages for propensities to vote, party identification and candidate evaluation by group

\begin{tabular}{|c|c|c|c|c|}
\hline & \multirow{2}{*}{$\begin{array}{c}\text { GLES } \\
\text { Natives }\end{array}$} & \multicolumn{3}{|c|}{ IMGES } \\
\hline & & All immigrant-origin voters & Only Turkish descent & Only (post-)Soviet descent \\
\hline \multicolumn{5}{|l|}{ PTV } \\
\hline CDU/CSU & 2.8 & 10.9 & 6.0 & 15.2 \\
\hline SPD & 2.8 & 10.5 & 5.8 & 14.7 \\
\hline Left Party & 3.0 & 14.8 & 9.1 & 19.9 \\
\hline Greens & 3.0 & 12.5 & 6.8 & 17.5 \\
\hline FDP & 3.2 & 20.7 & 15.7 & 25.1 \\
\hline AfD & 2.7 & 15.7 & 8.5 & 22.0 \\
\hline Party ID & 3.2 & 9.6 & 7.7 & 11.2 \\
\hline Issue orientation & 8.1 & 18.1 & 12.3 & 23.3 \\
\hline \multicolumn{5}{|c|}{ Candidate evaluations } \\
\hline CDU/CSU & 1.3 & 6.7 & 6.9 & 6.5 \\
\hline SPD & 5.8 & 17.6 & 11.9 & 22.6 \\
\hline Left Party & 14.6 & 31.1 & 24.9 & 36.6 \\
\hline Greens & 9.4 & 25.1 & 11.2 & 37.3 \\
\hline FDP & 14.4 & 40.7 & 35.3 & 45.4 \\
\hline AfD & 19.8 & 42.8 & 37.3 & 47.6 \\
\hline
\end{tabular}

Notes: Natives: data from GLES. Others: data from IMGES. Grouped together: 'don't know', no answer, 'don't know the party/politician'. CSU for respondents from Bavaria; CDU for all other respondents. Reading example: 10.9 per cent of immigrant-origin voters did not indicate their personal likelihood to vote for the CDU/CSU (6.0 per cent of Germans of Turkish descent, 15.2 per cent of Germans of (post-)Soviet descent and 2.8 per cent of native voters).

Candidate evaluations of smaller parties reveal the largest proportions of missing values, with 14.4 per cent of native voters, 40.7 per cent of immigrant-origin voters overall, 35.3 per cent of Germans of Turkish descent and 45.4 per cent of Germans of (post-)Soviet descent not giving an assessment of the leading candidate of the liberal FDP. If our theoretical expectations on the formative effects of the immigrant-specific variables $(\mathrm{H} 2 \mathrm{c}, \mathrm{H} 3 \mathrm{c}, \mathrm{H} 4 \mathrm{c})$ are correct, we would lose information stemming from these differences by dropping cases with missing data using a classic listwise-deletion procedure.

For both the regression and the path models, we thus used an imputation procedure for missing values, called 'multiple complete random imputation' (MCRI), introduced by Kroh (2006). The MCRI general procedure starts with setting a seed $(8,407)$ for reproducibility and sorting the dataset randomly. Afterwards, we started by creating a new random variable ranging from 0 to 1 , with a mean of 0.5 that is uniformly distributed. We then recoded this variable according to the weighted distribution of the original variable. In a last step, we substituted this generated value for all those with item non-response for the respective variable.

We repeated these procedures for the independent variable PTV, as well as for the dependent variables - party identification, candidate evaluations and issue competency - for all six political parties and the three voter groups separately (natives, Turkish descent and post-Soviet immigrants) to account for different distributions between parties and groups. This procedure guaranteed that we would find no artificial relationship for imputed cases between the imputed variables and others. ${ }^{4}$ We repeated this procedure five times and used Stata's Multiple Imputation (MI) framework to analyse the imputed datasets.

\section{Results}

Before testing for the standard electoral choice and immigrant-specific perspectives, we give a descriptive overview on the party preferences of immigrant-origin and native voters at the 2017 Bundestag election. In Table 3, we present the official election outcome in terms of second

\footnotetext{
${ }^{4}$ For such an artificial relationship, see Table SI 1, p. 2, Model 3b, in the Supplementary Material.
} 
Table 3. Party preferences of immigrant-origin and native voters at the 2017 Bundestag election

\begin{tabular}{|c|c|c|c|c|c|}
\hline & \multicolumn{3}{|c|}{ Second vote (percentage) } & \multicolumn{2}{|c|}{ PTV (mean) } \\
\hline & Official result & Natives (GLES) & Migrants (IMGES) & Natives (GLES) & Migrants (IMGES) \\
\hline $\mathrm{CDU} / \mathrm{CSU}$ & 33.0 & 30 & 23 & 5.5 & 5.2 \\
\hline SPD & 20.5 & 20 & 23 & 5.6 & 5.6 \\
\hline Left Party & 9.2 & 11 & 19 & 3.4 & 4.4 \\
\hline Greens & 8.9 & 13 & 11 & 4.4 & 4.1 \\
\hline FDP & 10.7 & 12 & 9 & 4.2 & 3.9 \\
\hline AfD & 12.6 & 10 & 8 & 1.3 & 1.7 \\
\hline Other & 5.1 & 4 & 7 & & \\
\hline $\mathrm{N}$ & & 1,571 & 576 & $1,631-1,637$ & $784-891$ \\
\hline
\end{tabular}

votes (that is, the party vote in the German system), as well as the reported vote choice and the PTV for native and immigrant-origin voters.

The official result of the 2017 election was of historically low support for the two government parties (CDU/CSU and SPD) and the re-entry of the FDP into parliament. Most decisively, the radical-right $\mathrm{AfD}$ entered the Bundestag for the first time. In general, these official results are backed up by the GLES, even though we see an under-reporting for the AfD vote choice among native voters. This pattern recurs in the PTV, with many German voters showing a low willingness to support the AfD in general. Table 3 also shows that the number of respondents providing information on PTV is decisively higher than those reporting their vote choice. For immigrant-origin voters, the support pattern is more left-leaning than for natives: all right-wing parties (CDU/CSU, FDP and AfD) perform slightly worse among immigrant voters, while the traditional left-wing parties (SPD and the Left Party) perform better, the Greens being an exception. Important for our area of interest is that these differences among immigrant-origin and native voters can be observed by looking at the reported second vote as well as at the PTV the AfD being the only exception here. In the Supplementary Material (Table SI 2, p. 3), we provide the results for immigrant-origin voters and distinguish between Turkish-origin and (post-) Soviet-origin voters. Both groups differ sharply in their party support, the former group being much more left-leaning than the latter.

Starting with our analysis, in Table 4, we present the results of several multi-level models with stacked PTV as the dependent variable. In model 1, we estimate the Michigan model for the group of native voters with party identification, candidate evaluations and issue competence perceptions. It is not surprising that all of these variables significantly affect party preference among native voters, supporting a well-established finding for Germany. The effects of candidate orientation and party identification stand out here, with issue considerations being significant but far less important for explaining party preferences.

Model 2 estimates the same model for the group of immigrant-origin voters. The important finding here is that all Michigan model variables are also related to the party preferences of this group. At the same time, party identification and candidate assessment each play a weaker role for immigrant-origin voters, while issue orientations are somewhat stronger related to party support than we find for natives (see Table SI 3, p. 3, in the Supplementary Material). Given that party identification is a long-term concept acquired during political socialization, this difference between immigrant-origin and native voters is in line with our theoretical expectations. In summary, these results show that the Michigan model works well for both native and immigrant-origin voters, supporting the baseline hypothesis $(\mathrm{H} 1)$. While there are differences as to party preferences between the two groups (see Table 3), to a large extent, these can be explained by the standard electoral research perspective.

Let us now turn to the potential impact of the immigrant-specific variables. Starting with their direct effects, we add length of stay (H2a), ethnic identity (H3a) and discrimination experiences 
Table 4. Multi-level linear regression models on PTVs for native and immigrant-origin voters

\begin{tabular}{|c|c|c|c|c|c|}
\hline & $\begin{array}{l}\text { Model 1: } \\
\text { natives }\end{array}$ & $\begin{array}{l}\text { Model 2: } \\
\text { migrants }\end{array}$ & $\begin{array}{l}\text { Model 3: } \\
\text { migrants }\end{array}$ & $\begin{array}{l}\text { Model 4: } \\
\text { migrants }\end{array}$ & $\begin{array}{l}\text { Model 5: } \\
\text { migrants }\end{array}$ \\
\hline Party identification & $\begin{array}{l}3.37^{\star \star \star} \\
(0.11)\end{array}$ & $\begin{array}{l}2.38^{\star * \star} \\
(0.24)\end{array}$ & $\begin{array}{l}2.38^{\star \star \star} \\
(0.24)\end{array}$ & & \\
\hline Candidate evaluations & $\begin{array}{l}5.11^{\star \star \star} \\
(0.15)\end{array}$ & $\begin{array}{l}3.36^{\star * *} \\
(0.34)\end{array}$ & $\begin{array}{l}3.36^{\star \star *} \\
(0.34)\end{array}$ & & \\
\hline Issue orientations & $\begin{array}{l}0.81^{\star \star \star} \\
(0.13)\end{array}$ & $\begin{array}{l}2.09^{\star \star \star} \\
(0.36)\end{array}$ & $\begin{array}{l}2.09^{\star \star \star} \\
(0.36)\end{array}$ & & \\
\hline \multicolumn{6}{|l|}{ Immigrant-specific factors } \\
\hline Length of stay & & & $\begin{array}{c}-0.15 \\
(0.36)\end{array}$ & $\begin{array}{c}-0.65 \\
(0.35)\end{array}$ & $\begin{array}{c}-0.05 \\
(0.23)\end{array}$ \\
\hline Ethnic identity & & & $\begin{array}{r}-0.04 \\
(0.05)\end{array}$ & $\begin{array}{c}-0.05 \\
(0.05)\end{array}$ & $\begin{array}{c}-0.04 \\
(0.05)\end{array}$ \\
\hline Discrimination & & & $\begin{array}{c}0.02 \\
(0.08)\end{array}$ & $\begin{array}{r}-0.12 \\
(0.10)\end{array}$ & $\begin{array}{c}-0.11 \\
(0.10)\end{array}$ \\
\hline \multicolumn{6}{|l|}{ Controls } \\
\hline Age & $\begin{array}{l}-1.03^{\star \star \star} \\
(0.17)\end{array}$ & $\begin{array}{r}-0.66^{\star} \\
(0.31)\end{array}$ & $\begin{array}{r}-0.79^{\star} \\
(0.40)\end{array}$ & $\begin{array}{r}-0.91^{\star} \\
(0.43)\end{array}$ & \\
\hline Gender: male & $\begin{array}{r}-0.04 \\
(0.07)\end{array}$ & $\begin{array}{r}-0.01 \\
(0.10)\end{array}$ & $\begin{array}{r}-0.01 \\
(0.10)\end{array}$ & $\begin{array}{r}-0.00 \\
(0.11)\end{array}$ & \\
\hline Education & $\begin{array}{l}0.59^{\star \star \star} \\
(0.10)\end{array}$ & $\begin{array}{c}0.22 \\
(0.14)\end{array}$ & $\begin{array}{c}0.22 \\
(0.14)\end{array}$ & $\begin{array}{r}0.33^{*} \\
(0.16)\end{array}$ & \\
\hline Political interest & $\begin{array}{c}0.11 \\
(0.15)\end{array}$ & $\begin{array}{c}0.24 \\
(0.22)\end{array}$ & $\begin{array}{c}0.24 \\
(0.23)\end{array}$ & $\begin{array}{c}0.29 \\
(0.25)\end{array}$ & \\
\hline $\begin{array}{l}\text { (Post-)Soviet descent (base: } \\
\text { Turkish) }\end{array}$ & & $\begin{array}{c}-0.02 \\
(0.11)\end{array}$ & $\begin{array}{r}-0.06 \\
(0.14)\end{array}$ & $\begin{array}{r}-0.10 \\
(0.15)\end{array}$ & \\
\hline \multicolumn{6}{|c|}{ Controlling for party (reference cat.: CDU/CSU) } \\
\hline SPD & $\begin{array}{l}0.92^{\star \star \star} \\
(0.09)\end{array}$ & $\begin{array}{l}1.16^{\star \star \star} \\
(0.24)\end{array}$ & $\begin{array}{l}1.16^{\star \star \star} \\
(0.24)\end{array}$ & $\begin{array}{l}0.38 \\
(0.28)\end{array}$ & $\begin{array}{c}0.38 \\
(0.28)\end{array}$ \\
\hline Left Party & $\begin{array}{l}-0.87^{\star * *} \\
(0.10)\end{array}$ & $\begin{array}{c}-0.01 \\
(0.25)\end{array}$ & $\begin{array}{c}-0.01 \\
(0.25)\end{array}$ & $\begin{array}{l}-0.75^{\star *} \\
(0.28)\end{array}$ & $\begin{array}{l}-0.75^{\star *} \\
(0.28)\end{array}$ \\
\hline Greens & $\begin{array}{r}-0.07 \\
(0.10)\end{array}$ & $\begin{array}{c}0.29 \\
(0.31)\end{array}$ & $\begin{array}{c}0.29 \\
(0.31)\end{array}$ & $\begin{array}{l}-0.96^{\star \star} \\
(0.33)\end{array}$ & $\begin{array}{l}-0.96^{\star \star} \\
(0.33)\end{array}$ \\
\hline FDP & $\begin{array}{r}-0.09 \\
(0.09)\end{array}$ & $\begin{array}{c}-0.12 \\
(0.30)\end{array}$ & $\begin{array}{c}-0.12 \\
(0.30)\end{array}$ & $\begin{array}{l}-1.37^{\star \star \star} \\
(0.28)\end{array}$ & $\begin{array}{l}-1.37^{\star \star \star} \\
(0.28)\end{array}$ \\
\hline AfD & $\begin{array}{l}-0.84^{\star \star \star} \\
(0.12)\end{array}$ & $\begin{array}{l}-1.44^{\star \star \star} \\
(0.22)\end{array}$ & $\begin{array}{l}-1.44^{\star \star \star} \\
(0.22)\end{array}$ & $\begin{array}{l}-3.69^{\star \star \star} \\
(0.24)\end{array}$ & $\begin{array}{l}-3.69^{\star \star \star} \\
(0.24)\end{array}$ \\
\hline Constant & $\begin{array}{l}1.19^{\star \star \star} \\
(0.18)\end{array}$ & $\begin{array}{l}1.94^{\star \star \star} \\
(0.30)\end{array}$ & $\begin{array}{l}2.24^{\star \star \star} \\
(0.56)\end{array}$ & $\begin{array}{l}5.86^{\star \star \star} \\
(0.49)\end{array}$ & $\begin{array}{l}5.43^{\star \star \star} \\
(0.31)\end{array}$ \\
\hline $\begin{array}{l}\text { Variance (Level } 2 \text { random } \\
\text { intercept) }\end{array}$ & $\begin{array}{l}-0.25^{\star * *} \\
(0.06)\end{array}$ & $\begin{array}{c}-0.06 \\
(0.06)\end{array}$ & $\begin{array}{c}-0.06 \\
(0.06)\end{array}$ & $\begin{array}{c}-0.08 \\
(0.07)\end{array}$ & $\begin{array}{l}-0.06 \\
(0.07)\end{array}$ \\
\hline Variance (Level 1 error) & $\begin{array}{l}0.82^{\star \star \star} \\
(0.01)\end{array}$ & $\begin{array}{l}0.83^{\star \star \star} \\
(0.03)\end{array}$ & $\begin{array}{l}0.83^{\star \star \star} \\
(0.03)\end{array}$ & $\begin{array}{l}1.02^{\star \star \star} \\
(0.02)\end{array}$ & $\begin{array}{l}1.03^{\star \star \star} \\
(0.02)\end{array}$ \\
\hline $\mathrm{N}$ & 10,308 & 5,412 & 5,412 & 5,412 & 5,412 \\
\hline Mean AIC & 44,891 & 25,997 & 26,002 & 28,104 & 28,110 \\
\hline Mean BIC & 45,023 & 25,989 & 26,013 & 28,128 & 28,101 \\
\hline
\end{tabular}

Notes: Weighted and stacked data, robust standard errors in parentheses, mean coefficients after multiple imputation analyses with $\mathrm{m}=5$; all continuous independent variables recoded to range from 0 to $1 .{ }^{\star \star \star} p<0.001 ;{ }^{\star \star} p<0.01 ;{ }^{\star} p<0.05$.

(H4a) in Model 3. It turns out that their inclusion leaves the effects of the Michigan model variables virtually unaffected because none of the immigrant-specific variables is significantly related to the party preferences of immigrant-origin voters. Showing that this finding is not due to multicollinearity, we additionally run a model without the Michigan model variables (Model 4) and, finally, also drop the controls (Model 5). In none of these models are the effects of length of stay, ethnic identity and discrimination significant. A Wald test $(\mathrm{F}[3,136.4]=0.27, p=0.884)$ reveals that even their joint inclusion does not lead to a statistically significant improvement of the standard Michigan model. Thus, we can only conclude that immigrant-specific approaches do not matter directly in the German context, giving no support for H2a, H3a or H4a. Given the 
Table 5. The $p$-values of the product-term variables of the immigrant-specific and Michigan model variables

\begin{tabular}{lccc}
\hline & Party ID & Candidate evaluations & Issue orientations \\
\hline Length of stay & 0.139 & 0.021 & 0.622 \\
Ethnic identification & 0.847 & 0.462 & 0.488 \\
Discrimination & 0.129 & 0.486 & 0.682 \\
\hline
\end{tabular}

Note: Mean $p$-values based on Table A1, Model 9, in the Appendix.

encompassing literature on the relevance of immigrant-specific variables for political participation and the few previous studies addressing their impact on vote choice, this is a noteworthy finding. Also, we come to the same conclusion for the full Model 3 when differentiating further between Turkish-origin and (post-)Soviet-origin voters (see Table SI 7 in the Supplementary Material).

Next, we analyse the potential moderating effects of the immigrant-specific variables, asking: do they alter the effects of party identification or candidate or issue orientations? We find limited support for this possibility. Table 5 shows a summary of a total of nine tests for the interaction effects between the three immigrant-specific variables and the three Michigan model variables. For this, we rerun Model 3, adding the product-term variables first separately for each immigrantspecific variable, and then all nine in one model (for the complete models M6-M9, see Table A1 in the Appendix). In contrast to the theoretical expectations, eight of these interaction models do not yield significant improvements, the only exception being the interaction between the time spent in Germany and the effect of candidate evaluations. While this moderation effect gives limited support for $\mathrm{H} 2 \mathrm{~b}$ and is theoretically founded (migrant voters might gather more knowledge about German candidates the longer they live in the country and use this information for their vote choices), we would have expected length of stay in Germany to play an even more decisive role in moderating the effect of party identification. However, neither ethnic identity nor discrimination significantly moderate the Michigan model's core variables, giving no support for $\mathrm{H} 3 \mathrm{~b}$ or H4b.

Summarizing our empirical evidence so far, we were unable to find any direct effects and almost no moderating effects of the immigrant-specific variables. While this holds little support for our theoretical expectations, it is too early to state that such approaches are inadequate for explaining immigrant-origin voters' party preferences. It might be that immigrant-specific approaches initially affect the prerequisites of the Michigan model, that is, the existence of attitudes and attachments towards parties, candidates and issues. From this perspective, the large numbers of missing values for the Michigan model's core variables (see Table 2) might be related to the immigrant-specific variables: longer-term immigrants with a strong German identity and little experience with discrimination may report significantly fewer item non-responses than recently arrived immigrants with a strong ethnic identity and strong discrimination experiences.

In order to test for such formative effects $(\mathrm{H} 2 \mathrm{c}, \mathrm{H} 3 \mathrm{c}, \mathrm{H} 4 \mathrm{c})$, we employ path models to our sample of immigrant-origin voters. In the basic model, the variables age, education, gender and political interest affect party identification, which, in itself, has a direct effect on PTV. There are also two indirect effects of party identification on PTV through candidate and issue orientations. The two short-term Michigan model factors correlate with each other and, additionally, have a direct effect on PTV. Lastly, the level of PTV varies by immigrant group. To these models, we now add four dummy variables for item non-response, taking up the value of 1 if the respondent did not answer the question, and 0 if they did. Hence, we analyse how the immigrant-specific factors affect these missing-value dummy variables, presenting the results in Table 6.

Altogether, we estimate four models: Models 10-12 each include one immigrant-specific factor, whereas Model 13 allows a comparison of all three. In contrast to the negligible direct and 
Table 6. The effect of immigrant-specific factors on missingness of the Michigan model's core variables (only immigrant-origin voters), path models

\begin{tabular}{|c|c|c|c|c|}
\hline & $\begin{array}{l}\text { Model 10: including } \\
\text { length of stay }\end{array}$ & $\begin{array}{l}\text { Model 11: including } \\
\text { ethnic identity }\end{array}$ & $\begin{array}{l}\text { Model 12: including } \\
\text { discrimination }\end{array}$ & $\begin{array}{c}\text { Model 13: including all } \\
\text { immigrant-specific variables }\end{array}$ \\
\hline \multicolumn{5}{|c|}{ DV: missing party ID $\leftarrow$} \\
\hline $\begin{array}{l}\text { Length of stay in } \\
\text { Germany }\end{array}$ & $\begin{array}{l}-0.14^{\star \star \star} \\
(0.02)\end{array}$ & & & $\begin{array}{l}-0.15^{\star \star \star} \\
(0.02)\end{array}$ \\
\hline Ethnic identity & & $\begin{array}{c}-0.01 \\
(0.01)\end{array}$ & & $\begin{array}{c}-0.01 \\
(0.01)\end{array}$ \\
\hline $\begin{array}{l}\text { Discrimination } \\
\text { index }\end{array}$ & & & $\begin{array}{c}-0.01 \\
(0.01)\end{array}$ & $\begin{array}{l}0.00 \\
(0.01)\end{array}$ \\
\hline Constant & $\begin{array}{c}0.18 \\
(0.02)\end{array}$ & $\begin{array}{c}0.12 \\
(0.03)\end{array}$ & $\begin{array}{c}0.09 \\
(0.01)\end{array}$ & $\begin{array}{l}0.23 \\
(0.04)\end{array}$ \\
\hline \multicolumn{5}{|c|}{ DV: missing candidate evaluation $\leftarrow$} \\
\hline $\begin{array}{l}\text { Length of stay in } \\
\text { Germany }\end{array}$ & $\begin{array}{l}-0.25^{\star \star \star} \\
(0.04)\end{array}$ & & & $\begin{array}{l}-0.22^{\star \star \star} \\
(0.04)\end{array}$ \\
\hline Ethnic identity & & $\begin{array}{r}0.02^{*} \\
(0.01)\end{array}$ & & $\begin{array}{r}0.02^{*} \\
(0.01)\end{array}$ \\
\hline $\begin{array}{l}\text { Discrimination } \\
\text { index }\end{array}$ & & & $\begin{array}{l}-0.07^{\star \star \star} \\
(0.01)\end{array}$ & $\begin{array}{c}-0.06^{\star \star \star} \\
(0.01)\end{array}$ \\
\hline Constant & $\begin{array}{c}0.44 \\
(0.03)\end{array}$ & $\begin{array}{l}0.20 \\
(0.04)\end{array}$ & $\begin{array}{c}0.29 \\
(0.01)\end{array}$ & $\begin{array}{c}0.37 \\
(0.05)\end{array}$ \\
\hline \multicolumn{5}{|c|}{ DV: missing issue orientation $\leftarrow$} \\
\hline $\begin{array}{l}\text { Length of stay in } \\
\text { Germany }\end{array}$ & $\begin{array}{c}-0.19^{\star \star \star} \\
(0.04)\end{array}$ & & & $\begin{array}{l}-0.18^{\star \star \star} \\
(0.04)\end{array}$ \\
\hline Ethnic identity & & $\begin{array}{l}0.03^{\star \star \star} \\
(0.01)\end{array}$ & & $\begin{array}{l}0.03^{\star \star \star} \\
(0.00)\end{array}$ \\
\hline $\begin{array}{l}\text { Discrimination } \\
\text { index }\end{array}$ & & & $\begin{array}{c}-0.02 \\
(0.01)\end{array}$ & $\begin{array}{c}-0.02 \\
(0.01)\end{array}$ \\
\hline Constant & $\begin{array}{c}0.30 \\
(0.03)\end{array}$ & $\begin{array}{l}0.06 \\
(0.02)\end{array}$ & $\begin{array}{l}0.18 \\
(0.01)\end{array}$ & $\begin{array}{c}0.19 \\
(0.03)\end{array}$ \\
\hline
\end{tabular}

Notes: Weighted and stacked data, robust standard errors in parentheses, mean coefficients after multiple imputation analyses with $\mathrm{m}=5$; all continuous independent variables recoded to range from 0 to 1 . For the full table with all paths, see Table A2 in the Appendix. DV = dependent variable. ${ }^{* \star *} p<0.001 ;{ }^{* \star} p<0.01 ;{ }^{*} p<0.05$.

moderating effects reported so far, Table 6 indicates significant formative effects of the immigrant-specific variables on the presence of political attitudes and beliefs, regardless of whether we estimate these variables separately or jointly. The most relevant and consistent of these effects is caused by the length of stay in the country of residence: long-term immigrant-origin voters show decisively fewer non-responses on party identification, candidate evaluations and ascribed issue competences than more recently arrived immigrants. Comparing those Germans who have only spent a small fraction of their lives in Germany with those who have spent all of their lives there, we see an estimated decrease of 15 percentage points in the likelihood of not expressing any party identification, a decrease of 22 percentage points in the probability of not indicating a candidate evaluation and a decrease of 18 percentage points in the likelihood of not expressing an issue evaluation (Model 13). We see these sizeable effects as supporting $\mathrm{H} 2 \mathrm{c}$ and interpret them as deriving from immigrant-origin voters' greater knowledge of the core Michigan model variables, acquired during their years spent in Germany.

A comparable, but less coherent, picture emerges for ethnic identity: strong ethnic (that is, non-German) identifiers show more non-response for candidates (two percentage points) and issues (three percentage points) but not for party identity. While these effects are much smaller than the ones reported for time spent in Germany, we interpret them as indicating a lower interest in ethnic identifiers for German politics in general, especially for the more information-demanding and short-term Michigan model factors. For the long-term factor of party identity, strong ethnic identifiers might learn which party to vote for through their ethnic networks, which makes gathering knowledge about candidates and issues less relevant to them 
(see also Barreto 2007, Bergh and Bjørklund 2010). Together, these findings give some support for $\mathrm{H} 3 \mathrm{c}$.

Lastly, we look at the effects of discrimination. Here, only the path of candidate evaluations on the missing dummy is significant and negative (six percentage points): the more that immigrant-origin voters feel discriminated against, the more likely they are to report attitudes towards German candidates. While the null effects of discrimination on party identification and on issues remind us to interpret this finding carefully, there is little support for the interpretation that immigrants who have experienced discrimination show less interest in or even feel alienated from German politics, as this should have led to higher rates of item non-response. Rather, discriminated immigrant-origin voters seem to put more emphasis on getting to know which candidates might be responsible for discrimination, or they look out for candidates of their own ethnicity when casting their votes, thereby acquiring meaningful attitudes towards them ( $\mathrm{H} 4 \mathrm{c}$ ).

To corroborate our results, we also conducted several sensitivity analyses (see the Supplementary Material). We first estimated our models only for those respondents without missing values on the key variables to see if listwise deletion changed our findings (see Tables SI 4 and SI 5 in the Supplementary Material). We find similar results concerning the direction and significance of effects if we exclude those with missing values for party identification, candidate evaluations, issue orientations and propensity to vote for all analyses. Next, we estimated the models separately for the groups of voters and non-voters to look for differences between the politically mobilized and non-mobilized (see Tables SI 4, SI 5 and SI 6 in the Supplementary Material). We find the same significant results for direct effects and formative effects. For the moderating effects, only one out of nine product-term variables (the negative product-term of partisanship and discrimination) for the group of voters, and none for the group of non-voters, is statistically significant at the 5 per cent level. In general, our findings for direct, moderation and formative effects were very similar. Finally, we estimated all models for the group of Turkish-descent and (post-)Soviet-origin immigrant-origin voters (see Tables SI 7 and SI 8 in the Supplementary Material). The results confirm the applicability of the Michigan model for both subgroups and the meaninglessness of any direct and moderating effects of the immigrantspecific variables. The formative effects of length of stay, ethnic identity and discrimination, as indicated in the path models, hold for the subgroup of (post-)Soviet voters. For Turkish-descent voters, time spent in Germany lowers the number of item non-responses only for party identification, while ethnic identity and discrimination experiences show more ambiguous formative effects than we find for the group of all immigrant-origin voters (see Table SI 9 in the Supplementary Material). We also check whether the inclusion of income, coded as terciles and also including a category for missing values (12 per cent of respondents), changes the results. ${ }^{5}$ However, we still find no significant results for direct effects (see Table SI 10 in the Supplementary Material). For the moderating and formative effects (see Table SI 11 and Table SI 12 in the Supplementary Material, respectively), our results are also very similar. In general, length of stay in Germany shows larger and more coherent effects on item non-response for the Michigan model variables $(\mathrm{H} 2 \mathrm{c})$ than the other immigrant-specific variables $(\mathrm{H} 3 \mathrm{c}$ and $\mathrm{H} 4 \mathrm{c}){ }^{6}$

\section{Conclusions}

Migrant voters now make up a sizeable group in the electorate of many Western countries, but we know surprisingly little about the drivers of their party preferences. While some previous studies have taken up a standard electoral studies perspective - trying to explain immigrant-origin voters' party preferences with the same theories used for native voters - others have stressed the role of immigrant-specific variables. Here, we rigorously tested these perspectives against each other, using the Michigan model variables to account for the first perspective, and length of stay, ethnic

\footnotetext{
${ }^{5}$ We thank one of the anonymous reviewers for this suggestion.

${ }^{6} \mathrm{We}$ also ran additional analyses with state fixed effects. These additional models yielded no qualitatively different results.
} 
identity and discrimination as the most prominent variables for the second, immigrant-specific perspective. Focusing on Germany, a multiparty system with a very different immigrant-origin voter population in comparison with both the United States and the UK - but one much more representative of Continental Europe - we used the most recent, high-quality survey data to model the two distinct approaches.

In sum, the Michigan model was able to explain the party preferences of native and immigrant-origin voters well, with the slight variation that party identification is more important for the former, whereas issue orientations matter more for the latter. While this standard electoral studies perspective gets us far in understanding immigrant voters' party preferences, the most prominent immigrant-specific factors play a special role in adding to our understanding.

Our first main finding here is that immigrant-specific factors do not exercise any direct effects, nor do they moderate the effects of the Michigan model's core variables in a relevant way. These non-findings stand in sharp contrast to many previous contributions on immigrant-origin voters. It could simply be possible that we did not measure all immigrant-specific constructs optimally and, therefore, failed to find direct effects. We did collect these data ourselves, but we might have missed something. More interestingly, this might be due to differences in the political systems of the host societies or due to the fact that few previous studies have fully controlled for standard variables and immigrant-specific variables at the same time. As we also found some variation between the two biggest groups of immigrant-origin voters in Germany, a straightforward research design for future studies would be to analyse the party preferences of the same immigrant group across different host societies - a design currently prevented due to reasons of data availability.

Our second main finding might also motivate future studies to analyse the role of immigrant-specific variables well before the point in time when they are usually considered. While we find few direct and moderating effects, length of stay, ethnic identity and discrimination experiences do exert formative effects on the party preferences of immigrant-origin voters. Especially, immigrants who have spent a longer time in Germany are much abler and/or more willing to express their party identification and their candidate and issue orientations. Studies that focus exclusively on direct and moderating effects may thus underestimate the role of immigrant-specific factors, which seem to have much stronger effects at the beginning of standard electoral research models.

To the best of our knowledge, we are the first to explicitly analyse the reasons for such item non-response patterns among immigrant-origin voters. However, in their study on the party identities of Asian and Latino voters in the United States, Hajnal and Lee $(2006,138)$ report that from the standpoint of most conventional approaches to party identification ... about half of these immigration-based groups would likely be coded and discounted as "missing data"'. This seems to stand in stark contrast to recent findings from the UK, reporting a strong party identity among several immigrant groups for Labour (Heath et al. 2013, ch. 6). In any case, given the levels of item non-response for central political variables among both US and German immigrant groups, further analyses of their potential reasons and consequences for immigrants' political integration seem promising.

Supplementary Material. Online appendices are available at: https://doi.org/10.1017/S0007123421000302

Data Availability Statement. The data collected are publicly available (see Goerres, Spies, and Mayer 2020). Replication files for this article can be found at: https://doi.org/10.7910/DVN/MKRPE5.

Acknowledgements. Earlier drafts were presented at the European Political Science Association Annual Conference in Vienna in 2018, the German Political Science Association Triannual Conference in Frankfurt in 2018, the Political Studies Association's Specialist Group Annual Conference on Elections, Parties and Public Opinion at Royal Holloway in 2018, Sciences Po in December 2018, the Council for European Studies Annual Conference in Madrid 2019, and at our own workshop in Cologne in February 2019. We thank all commentators, especially Andreas Blätte, Aimie Bouju, Stephen Fisher, Hayfat Hamidou-Schmidt, Troels Fage Hedegaard, Aida Just, Melanie Kolbe, Laura Morales, Liza Mügge, Jannis Panagiotidis, Carolin Rapp, Karen Schönwälder, Maria Sobolewska, Oliver Strijbis and Floris Vermeulen. 
Author contributions. All authors contributed equally.

Financial Support. The study was financed by the German Research Foundation, Principal Investigators Achim Goerres and Dennis C. Spies (GO 1833/5-1, SP 1619).

Competing Interests. The authors declare that there are no conflicts of interest.

Ethical Standards. The data protection concept was developed together with the data protection officers of the universities of Duisburg-Essen and Cologne, and complies with all current European and German regulations. As part of this, all IMGES survey participants provided written consent and were compensated for their participation.

\section{References}

Abrajano MA, Alvarez RM and Nagler J (2008) The Hispanic vote in the 2004 presidential election: insecurity and moral concerns. The Journal of Politics 70(2), 368-382. doi: 10.1017/s0022381608080365.

Barreto MA (2007) İSí Se Puede! Latino candidates and the mobilization of Latino voters. American Political Science Review 101(3), 425-441. doi: 10.1017/S0003055407070293.

Barreto MA and Woods ND (2005) Latino voting behavior in an anti-Latino political context: the case of Los Angeles County. In Segura GM and Bowler S (eds), Diversity in Democracy: Minority Representation in the United States. Charlottesville, VA: University of Virginia Press, pp. 148-169.

Berger M, Galonska C and Koopmans R (2004) Political integration by a detour? Ethnic communities and social capital of migrants in Berlin. Journal of Ethnic and Migration Studies 30(3), 491-507. doi: 10.1080/13691830410001682052.

Bergh J and Bjørklund T (2010) The revival of group voting: explaining the voting preferences of immigrants in Norway. Political Studies 59(2), 308-327. doi: 10.1111/j.1467-9248.2010.00863.x.

Berinsky AJ (2008) Survey non-response. In Donsbach W and Traugott M (eds), The SAGE Handbook of Public Opinion Research. London: SAGE Publications Ltd, pp. 309-321.

Berry JW (1984) Multicultural policy in Canada: a social psychological analysis. Canadian Journal of Behavioural Science/ Revue canadienne des sciences du comportement 16(4), 353-370. doi: 10.1037/h0080859.

Bird K, Saalfeld T and Wüst AM (eds) (2011) The Political Representation of Immigrants and Minorities: Voters, Parties and Parliaments in Liberal Democracies. New York, NY, and Abingdon: Routledge.

Bishin BG and Klofstad CA (2012) The political incorporation of Cuban Americans: why won't Little Havana turn blue? Political Research Quarterly 65(3), 586-599. doi: 10.1177/1065912911414589.

Blank RM, Dabady M and Citro CF (2004) Measuring Racial Discrimination. Washington, DC: National Academies Press.

Cain BE, Kiewiet DR and Uhlaner CJ (1991) The acquisition of partisanship by Latinos and Asian Americans. American Journal of Political Science 35(2), 390. doi: 10.2307/2111368.

Campbell A et al. (1960) The American Voter. Chicago, IL: University of Chicago Press.

Citrin J et al. (1975) Personal and political sources of political alienation. British Journal of Political Science 5(1), 1-31.

Dancygier RM and Saunders EN (2006) A new electorate? Comparing preferences and partisanship between immigrants and natives. American Journal of Political Science 50(4), 962-981.

Dawson MC (1994) Behind the Mule: Race and Class in African-American Politics. Princeton, NJ: Princeton University Press.

De la Garza RO and Cortina J (2007) Are Latinos Republicans but just don't know it? The Latino vote in the 2000 and 2004 presidential elections. American Politics Research 35(2), 202-223. doi: 10.1177/1532673X06294885.

De la Garza RO, Falcon A and Garcia FC (1996) Will the real Americans please stand up: Anglo and Mexican-American support of core American political values. American Journal of Political Science 40(2), 335-351. doi: 10.2307/2111627.

DeSipio L and Uhlaner CJ (2007) Immigrant and native: Mexican American presidential vote choice across immigrant generations. American Politics Research 35(2), 176-201. doi: 10.1177/1532673X06296197.

Diehl C and Blohm M (2001) Apathy, adaptation or ethnic mobilisation? On the attitudes of a politically excluded group. Journal of Ethnic and Migration Studies 27(3), 401-420. doi: 10.1080/136918301200266149.

Ersanilli E and Koopmans R (2010) Rewarding integration? Citizenship regulations and the socio-cultural integration of immigrants in the Netherlands, France and Germany. Journal of Ethnic and Migration Studies 36(5), 773-791.

Fennema M and Tillie J (1999) Political participation and political trust in Amsterdam: civic communities and ethnic networks. Journal of Ethnic and Migration Studies 25(4), 703-726.

Fisher SD et al. (2014) Candidate ethnicity and vote choice in Britain. British Journal of Political Science 45(4), 883-905. doi: $10.1017 / \mathrm{s} 0007123413000562$.

Fox S (2020) Political alienation and referendums: how political alienation was related to support for Brexit. British Politics 6, 16-35. doi: 10.1057/s41293-020-00134-8.

Fraga BL (2018) The Turnout Gap: Race, Ethnicity, and Political Inequality in a Diversifying America. Cambridge: Cambridge University Press.

Goerres A, Mayer SJ and Spies DC (2020) Immigrant voters against their will: a focus group analysis of identities, political issues and party allegiances among German resettlers during the 2017 Bundestag election campaign. Journal of Ethnic and Migration Studies 46(7), 1205-1222. 
Goerres A, Mayer SJ and Spies DC (2021) Replication Data for: A New Electorate? Explaining the Party Preferences of Immigrant-Origin Voters at the 2017 Bundestag Election, https://doi.org/10.7910/DVN/MKRPE5. Harvard Dataverse, V1, UNF:6:0iI5YEApgB/F9e7vbswmUg== [fileUNF].

Goerres A, Spies DC and Mayer SJ (2020) Immigrant German Election Study (IMGES): ZA7495 Data File Version 1.0.1. Cologne, Germany: GESIS Data Archive. doi: 10.4232/1.13544.

Hajnal Z and Lee T (2006) Out of line: immigration and party identification among Latinos and Asian Americans. In Lee T, Ramakrishnan K and Ramirez R (eds), Transforming Politics, Transforming America: The Political and Civic Incorporation of Immigrants in the United States. Charlottesville, VA: University of Virginia Press, pp. 129-150.

Hamidou-Schmidt $\mathbf{H}$ and Mayer SJ (2021) The relation between social identities and outgroup hostility among German immigrant-origin citizens. Political Psychology 42(2), 311-331.

Heath AF et al. (2013) The Political Integration of Ethnic Minorities in Britain. Oxford: Oxford University Press.

Jacobs D and Tillie J (2004) Introduction: social capital and political integration of migrants. Journal of Ethnic and Migration Studies 30(3), 419-427.

Johann D et al. (2016) Alternative Messverfahren rechtspopulistischen Wählens im Vergleich: Empirische Erkenntnisse aus Deutschland und Österreich [Alternative measurement approaches for right-populist vote choices in comparison: Empirical evidence from Germany and Austria.]. In Schoen H and Weßels B (eds), Wahlen und Wähler: Analysen aus Anlass der Bundestagswahl 2013 [Elections and Voters: Analyses for the Federal German Election 2013]. Wiesbaden: Springer Fachmedien Wiesbaden, pp. 447-470.

Johnston R (2006) Party identification: unmoved mover or sum of preferences? Annual Review of Political Science 9(1), 329351. doi: 10.1146/annurev.polisci.9.062404.170523.

Krämer J and Rattinger H (1997) The proximity and the directional theories of issue voting: comparative results for the USA and Germany. European Journal of Political Research 32(1), 1-29. doi: 10.1111/1475-6765.00329.

Krieger N (1999) Embodying inequality: a review of concepts, measures, and methods for studying health consequences of discrimination. International Journal of Health Services: Planning, Administration, Evaluation 29(2), 295-352. doi: 10.2190/M11W-VWXE-KQM9-G97Q.

Kroh M (2006) Taking 'don't knows' as valid responses: a multiple complete random imputation of missing data. Quality \& Quantity 40(2), 225-244. doi: 10.1007/s11135-005-5360-3.

Kroh M and Tucci I (2010) The party identification of Germany's immigrant population: parties should not fear eased naturalization requirements. DIW Weekly Report 6(4), 20-26.

Massey DS (1986) The settlement process among Mexican migrants to the United States. American Sociological Review 51(5), 670. doi: $10.2307 / 2095492$.

Neundorf A and Adams J (2018) The micro-foundations of party competition and issue ownership: the reciprocal effects of citizens' issue salience and party attachments. British Journal of Political Science 48(2), 385-406. doi: 10.1017/ S0007123415000642.

Ojeda C and Pacheco J (2017) Health and voting in young adulthood. British Journal of Political Science 6, 1-24. doi: $10.1017 /$ S0007123417000151.

Oskooii KAR (2018) Perceived discrimination and political behavior. British Journal of Political Science 50(3), 867-892. doi: $10.1017 /$ S0007123418000133.

Pantoja AD and Segura GM (2003) Does ethnicity matter? Descriptive representation in legislatures and political alienation among Latinos. Social Science Quarterly 84(2), 441-460.

Pérez E (2015) Xenophobic rhetoric and its political effects on immigrants and their co-ethnics. American Journal of Political Science 59(3), 549-564.

Ramakrishnan SK and Espenshade TJ (2001) Immigrant incorporation and political participation in the United States. International Migration Review 35(3), 870-909.

Ramírez R (2013) Mobilizing Opportunities: The Evolving Latino Electorate and the Future of American Politics. Race, Ethnicity, and Politics. Charlottesville, VA: University of Virginia Press.

Reichert F (2013) Kognitive Politisierung bei Studierenden mit türkischer Migrationsgeschichte. Zum Einfluss von politischem Interesse und politischen Kompetenzen auf politisches Handeln sowie zur Rolle kollektiver Identitäten im Prozess kognitiver Politisierung [Cognitive politicization among university students with Turkish migration history. On the influence of political interest and political competences on political action, and the role of collective identities in cognitive politicization]. München, Germany: De Gruyter Oldenbourg.

Rekker R et al. (2019) The formation of party preference in adolescence and early adulthood: how and when does it occur in the multiparty context of the Netherlands? Young (Stockholm, Sweden) 27(1), 48-68.

Riphahn RT and Serfling O (2005) Item non-response on income and wealth questions. Empirical Economics 30(2), 521-538.

Roßteutscher S et al. (2017) Post-election Cross Section (GLES 2017): ZA6801 Data File Version 1.0.0. Cologne: GESIS Data Archive.

Rubin DB, Stern HS and Vehovar V (1995) Handling 'don't know' survey responses: the case of the Slovenian plebiscite. Journal of the American Statistical Association 90(431), 822-828. doi: 10.1080/01621459.1995.10476580. 
Rumbaut RG (2005) Turning points in the transition to adulthood: determinants of educational attainment, incarceration, and early childbearing among children of immigrants. Ethnic and Racial Studies 28(6), 1041-1086. doi: 10.1080/ 01419870500224349.

Saggar S (2000) Race and Representation: Electoral Politics and Ethnic Pluralism in Britain. Manchester: Manchester University Press.

Sanchez GR (2006) The role of group consciousness in political participation among Latinos in the United States. American Politics Research 34(4), 427-450. doi: 10.1177/1532673X05284417.

Sanders D et al. (2014) The calculus of ethnic minority voting in Britain. Political Studies 62(2), 230-251. doi: 10.1111/ 1467-9248.12040.

Schildkraut DJ (2005) The rise and fall of political engagement among Latinos: the role of identity and perceptions of discrimination. Political Behavior 27(3), 285-312. doi: 10.1007/s11109-005-4803-9.

Simon B, Reichert F and Grabow O (2013) When dual identity becomes a liability: identity and political radicalism among migrants. Psychological Science 24(3), 251-257. doi: 10.1177/0956797612450889.

Southwell P (2012) Political alienation: behavioral implications of efficacy and trust in the 2008 U.S. presidential election. Review of European Studies 4(2), 71-77. doi: 10.5539/res.v4n2p71.

Spies DC, Mayer SJ and Goerres A (2020) What are we missing? Explaining immigrant-origin voter turnout with standard and immigrant-specific theories. Electoral Studies 1-6. doi: 10.1016/j.electstud.2019.102103.

Stokes AK (2003) Latino group consciousness and political participation. American Politics Research 31(4), 361-378. doi: $10.1177 / 1532673 X 03031004002$.

Tajfel H and Turner JC (1979) An integrative theory of intergroup conflict. In Austin WG and Worchel S (eds), The Social Psychology of Intergroup Relations. Monterey, CA: Brooks/Cole Publishing, pp. 33-47.

Teney C et al. (2010) Ethnic voting in Brussels: voting patterns among ethnic minorities in Brussels (Belgium) during the 2006 local elections. Acta Politica 45(3), 273-297. doi: 10.1057/ap.2009.25.

Tillie J (2004) Social capital of organisations and their members: explaining the political integration of immigrants in Amsterdam. Journal of Ethnic and Migration Studies 30(3), 529-541.

Tourangeau R and Yan T (2007) Sensitive questions in surveys. Psychological Bulletin 133(5), 859-883.

Tourangeau R, Rips LJ and Rasinski K (2012) The Psychology of Survey Response. Cambridge: Cambridge University Press.

Uhlaner CJ and Garcia FC (2005) Learning which party fits: experience, ethnic identity, and the demographic foundations of Latino party identification. In Segura GM and Bowler S (eds), Diversity in Democracy: Minority Representation in the United States. Race, Ethnicity, and Politics. Charlottesville, VA: University of Virginia Press, pp. 72-101.

Valdez Z (2011) Political participation among Latinos in the United States: the effect of group identity and consciousness. Social Science Quarterly 92(2), 466-482.

Van der Eijk C et al. (2006) Rethinking the dependent variable in voting behavior: on the measurement and analysis of electoral utilities. Electoral Studies 25(3), 424-447. doi: 10.1016/j.electstud.2005.06.012.

Van Tubergen F, Maas I and Flap H (2004) The economic incorporation of immigrants in 18 Western societies: origin, destination, and community effects. American Sociological Review 69(5), 704-727.

Wals SC (2013) Made in the USA? Immigrants' imported ideology and political engagement. Electoral Studies 32(4), 756767. doi: 10.1016/j.electstud.2013.05.032.

Wimmer A and Soehl T (2014) Blocked acculturation: cultural heterodoxy among Europe's immigrants. American Journal of Sociology 120(1), 146-186. doi: 10.1086/677207.

Wüst AM (2004) Naturalised citizens as voters: behaviour and impact. German Politics 13(2), 341-359. doi: 10.1080/ 0964400042000229972.

Cite this article: Goerres A, Mayer SJ, Spies DC (2022). A New Electorate? Explaining the Party Preferences of ImmigrantOrigin Voters at the 2017 Bundestag Election. British Journal of Political Science 52, 1032-1054. https://doi.org/10.1017/ S0007123421000302 
Table A1. Multi-level linear regression on propensities to vote, with immigrant-specific factors as moderators of the Michigan variables, only immigrant voters

\begin{tabular}{|c|c|c|c|c|}
\hline & $\begin{array}{l}\text { Model 6: interaction } \\
\text { with length of stay }\end{array}$ & $\begin{array}{l}\text { Model } 7: \text { interaction } \\
\text { with ethnic identity }\end{array}$ & $\begin{array}{l}\text { Model 8: interaction with } \\
\text { discrimination }\end{array}$ & $\begin{array}{l}\text { Model 9: full } \\
\text { model }\end{array}$ \\
\hline \multirow[t]{2}{*}{ Party identification } & 1.44 & $2.42^{\star}$ & $2.42^{\star \star \star}$ & 1.42 \\
\hline & $(0.80)$ & $(0.92)$ & $(0.28)$ & (1.19) \\
\hline \multirow[t]{2}{*}{ Candidate evaluations } & $2.00^{\star \star \star}$ & $4.03^{\star \star \star}$ & $3.32^{\star \star \star}$ & $2.51^{\star}$ \\
\hline & $(0.58)$ & $(0.92)$ & $(0.32)$ & (1.13) \\
\hline \multirow[t]{2}{*}{ Issue orientations } & $2.80^{\star \star}$ & 1.83 & $2.04^{\star \star \star}$ & 2.62 \\
\hline & $(0.92)$ & $(1.17)$ & $(0.33)$ & $(1.35)$ \\
\hline \multicolumn{5}{|l|}{ Immigrant-specific factors } \\
\hline \multirow[t]{2}{*}{ Length of stay in Germany } & $-1.23^{\star}$ & & & $-1.20^{\star}$ \\
\hline & $(0.51)$ & & & $(0.53)$ \\
\hline \multirow[t]{2}{*}{ Ethnic identity } & & 0.05 & & 0.03 \\
\hline & & $(0.11)$ & & $(0.11)$ \\
\hline \multirow[t]{2}{*}{ Discrimination index } & & & -0.08 & -0.04 \\
\hline & & & & $(0.10)$ \\
\hline \multirow[t]{2}{*}{ Length of stay $\times$ party ID } & 1.27 & & & 1.33 \\
\hline & $(1.13)$ & & & $(1.09)$ \\
\hline \multirow{2}{*}{$\begin{array}{l}\text { Length of stay } \times \text { candidate } \\
\text { evaluations }\end{array}$} & $2.14^{\star \star}$ & & & $1.99^{\star}$ \\
\hline & $(0.75)$ & & & $(0.78)$ \\
\hline \multirow{2}{*}{$\begin{array}{l}\text { Length of stay } \times \text { issue } \\
\text { orientations }\end{array}$} & -1.13 & & & -1.05 \\
\hline & $(1.24)$ & & & $(1.23)$ \\
\hline \multirow[t]{2}{*}{ Ethnic identity $\times$ party ID } & & -0.04 & & 0.03 \\
\hline & & $(0.24)$ & & $(0.23)$ \\
\hline \multirow{2}{*}{$\begin{array}{l}\text { Ethnic identity } \times \\
\text { candidate evaluations }\end{array}$} & & -0.17 & & -0.14 \\
\hline & & $(0.22)$ & & $(0.22)$ \\
\hline \multirow{2}{*}{$\begin{array}{l}\text { Ethnic identity } \times \text { issue } \\
\text { orientations }\end{array}$} & & 0.08 & & 0.02 \\
\hline & & $(0.31)$ & & $(0.31)$ \\
\hline \multirow{2}{*}{$\begin{array}{l}\text { Discrimination index } \times \\
\text { party ID }\end{array}$} & & & -0.45 & -0.46 \\
\hline & & & $(0.34)$ & $(0.31)$ \\
\hline \multirow{2}{*}{$\begin{array}{l}\text { Discrimination index } \times \\
\text { candidate evaluations }\end{array}$} & & & 0.31 & 0.25 \\
\hline & & & $(0.28)$ & $(0.27)$ \\
\hline \multirow{2}{*}{$\begin{array}{l}\text { Discrimination index } \times \\
\text { issue orientations }\end{array}$} & & & 0.10 & 0.07 \\
\hline & & & $(0.36)$ & $(0.36)$ \\
\hline \multicolumn{5}{|l|}{ Controls } \\
\hline \multirow[t]{2}{*}{ Age } & -0.66 & $-0.61^{*}$ & -0.58 & -0.70 \\
\hline & $(0.36)$ & $(0.29)$ & $(0.29)$ & $(0.36)$ \\
\hline \multirow[t]{2}{*}{ Gender: male } & -0.01 & -0.00 & -0.01 & -0.00 \\
\hline & $(0.10)$ & $(0.10)$ & $(0.10)$ & $(0.10)$ \\
\hline \multirow[t]{2}{*}{ Education } & 0.27 & 0.25 & 0.26 & 0.26 \\
\hline & $(0.14)$ & $(0.15)$ & $(0.15)$ & $(0.14)$ \\
\hline \multirow[t]{2}{*}{ Political interest } & 0.18 & 0.17 & 0.19 & 0.17 \\
\hline & $(0.20)$ & $(0.20)$ & $(0.20)$ & $(0.20)$ \\
\hline (Post-)Soviet descent & -0.08 & -0.03 & -0.03 & -0.08 \\
\hline & $(0.15)$ & $(0.11)$ & $(0.12)$ & $(0.15)$ \\
\hline Controlling for party (referen & cat.: $\mathrm{CDU} / \mathrm{CSU})$ & & & \\
\hline SPD & $1.11^{\star \star \star}$ & $1.18^{\star \star \star}$ & $1.19^{\star \star \star}$ & $1.13^{\star \star \star}$ \\
\hline & $(0.18)$ & $(0.18)$ & $(0.18)$ & $(0.18)$ \\
\hline Left Party & -0.08 & -0.07 & -0.06 & -0.07 \\
\hline & $(0.22)$ & $(0.21)$ & $(0.21)$ & $(0.21)$ \\
\hline Greens & 0.31 & 0.36 & 0.38 & 0.33 \\
\hline & $(0.24)$ & $(0.24)$ & $(0.25)$ & $(0.23)$ \\
\hline FDP & -0.16 & -0.13 & -0.13 & $\begin{array}{l}-0.16 \\
\text { (Continued) }\end{array}$ \\
\hline
\end{tabular}


Table A1. (Continued.)

\begin{tabular}{|c|c|c|c|c|}
\hline & $\begin{array}{l}\text { Model 6: interaction } \\
\text { with length of stay }\end{array}$ & $\begin{array}{l}\text { Model } 7 \text { : interaction } \\
\text { with ethnic identity }\end{array}$ & $\begin{array}{l}\text { Model 8: interaction with } \\
\text { discrimination }\end{array}$ & $\begin{array}{l}\text { Model 9: full } \\
\text { model }\end{array}$ \\
\hline & $(0.22)$ & $(0.22)$ & $(0.22)$ & $(0.22)$ \\
\hline \multirow[t]{2}{*}{ AfD } & $-1.46^{\star \star \star}$ & $-1.46^{\star \star \star}$ & $-1.47^{\star \star \star}$ & $-1.45^{\star \star \star}$ \\
\hline & $(0.22)$ & $(0.22)$ & $(0.22)$ & $(0.22)$ \\
\hline \multirow[t]{2}{*}{ Constant } & $2.84^{\star \star \star}$ & $1.77^{\star \star \star}$ & $1.95^{\star \star \star}$ & $2.74^{\star \star}$ \\
\hline & $(0.57)$ & $(0.51)$ & $(0.29)$ & $(0.77)$ \\
\hline \multirow{2}{*}{$\begin{array}{l}\text { Variance (Level } 2 \text { random } \\
\text { intercept) }\end{array}$} & -0.07 & -0.06 & -0.06 & -0.07 \\
\hline & $(0.06)$ & $(0.06)$ & $(0.06)$ & $(0.06)$ \\
\hline \multirow[t]{2}{*}{ Variance (Level 1 error) } & $0.81^{\star \star \star}$ & $0.81^{\star \star \star}$ & $0.81^{\star \star \star}$ & $0.81^{\star \star \star}$ \\
\hline & $(0.03)$ & $(0.03)$ & $(0.03)$ & $(0.03)$ \\
\hline $\mathrm{N}$ & 5,412 & 5,412 & 5,412 & 5,412 \\
\hline Mean AIC & 25,842 & 25,879 & 25,880 & 25,839 \\
\hline Mean BIC & 25,974 & 26,011 & 26,012 & 26,023 \\
\hline
\end{tabular}

Notes: Weighted and stacked data, robust standard errors in parentheses, mean coefficients after multiple imputation analyses with $\mathrm{m}=5$; all continuous independent variables recoded to range from 0 to $1 .{ }^{\star \star \star} p<0.001 ;{ }^{\star \star} p<0.01 ;{ }^{\star} p<0.05$.

Table A2. Full path models on PTV (only immigrant voters)

\begin{tabular}{|c|c|c|c|c|}
\hline & $\begin{array}{c}\text { Model 10: } \\
\text { including length of } \\
\text { stay }\end{array}$ & $\begin{array}{l}\text { Model } 11 \text { : including } \\
\text { ethnic identity }\end{array}$ & $\begin{array}{l}\text { Model 12: including } \\
\text { discrimination }\end{array}$ & $\begin{array}{l}\text { Model 13: including all } \\
\text { immigrant-specific variables }\end{array}$ \\
\hline \multicolumn{5}{|l|}{ MV party ID (dummy) $\leftarrow$} \\
\hline $\begin{array}{l}\text { Length of stay in } \\
\text { Germany }\end{array}$ & $-0.14^{\star \star \star}$ & & & $-0.15^{\star \star \star}$ \\
\hline & $(0.02)$ & & & $(0.02)$ \\
\hline Ethnic identity & & $\begin{array}{c}-0.01 \\
(0.01)\end{array}$ & & $\begin{array}{c}-0.01 \\
(0.01)\end{array}$ \\
\hline Discrimination index & & & $\begin{array}{c}-0.01 \\
(0.01)\end{array}$ & $\begin{array}{c}0.00 \\
(0.01)\end{array}$ \\
\hline Constant & $\begin{array}{c}0.18 \\
(0.02)\end{array}$ & $\begin{array}{c}0.12 \\
(0.03)\end{array}$ & $\begin{array}{c}0.09 \\
(0.01)\end{array}$ & $\begin{array}{c}0.23 \\
(0.04)\end{array}$ \\
\hline \multicolumn{5}{|c|}{ MV candidates (dummy) $\leftarrow$} \\
\hline $\begin{array}{l}\text { Length of stay in } \\
\text { Germany }\end{array}$ & $\begin{array}{c}-0.25^{\star \star \star} \\
(0.04)\end{array}$ & & & $\begin{array}{l}-0.22^{\star \star \star} \\
(0.04)\end{array}$ \\
\hline Ethnic identity & & $\begin{array}{r}0.02^{\star} \\
(0.01)\end{array}$ & & $\begin{array}{r}0.02^{*} \\
(0.01)\end{array}$ \\
\hline Discrimination index & & & $\begin{array}{l}-0.07^{\star \star \star} \\
(0.01)\end{array}$ & $\begin{array}{l}-0.06^{\star \star \star} \\
(0.01)\end{array}$ \\
\hline Constant & $\begin{array}{c}0.44 \\
(0.03)\end{array}$ & $\begin{array}{c}0.20 \\
(0.04)\end{array}$ & $\begin{array}{c}0.29 \\
(0.01)\end{array}$ & $\begin{array}{c}0.37 \\
(0.05)\end{array}$ \\
\hline \multicolumn{5}{|l|}{ MV issues (dummy) $\leftarrow$} \\
\hline $\begin{array}{l}\text { Length of stay in } \\
\text { Germany }\end{array}$ & $\begin{array}{c}-0.19^{\star \star \star} \\
(0.04)\end{array}$ & & & $\begin{array}{c}-0.18^{\star \star \star} \\
(0.04)\end{array}$ \\
\hline Ethnic identity & & $\begin{array}{l}0.03^{\star \star \star} \\
(0.01)\end{array}$ & & $\begin{array}{l}0.03^{\star \star \star *} \\
(0.00)\end{array}$ \\
\hline Discrimination index & & & $\begin{array}{c}-0.02 \\
(0.01)\end{array}$ & $\begin{array}{r}-0.02 \\
(0.01)\end{array}$ \\
\hline Constant & $\begin{array}{c}0.30 \\
(0.03)\end{array}$ & $\begin{array}{c}0.06 \\
(0.02)\end{array}$ & $\begin{array}{c}0.18 \\
(0.01)\end{array}$ & $\begin{array}{c}0.19 \\
(0.03)\end{array}$ \\
\hline \multicolumn{5}{|l|}{ Party ID $\leftarrow$} \\
\hline MV party ID & $\begin{array}{r}-0.00 \\
(0.03)\end{array}$ & $\begin{array}{r}-0.00 \\
(0.03)\end{array}$ & $\begin{array}{l}-0.00 \\
(0.03)\end{array}$ & $\begin{array}{r}-0.00 \\
(0.03)\end{array}$ \\
\hline Age & $\begin{array}{c}0.05 \\
(0.05)\end{array}$ & $\begin{array}{c}0.05 \\
(0.05)\end{array}$ & $\begin{array}{l}0.05 \\
(0.05)\end{array}$ & $\begin{array}{c}0.05 \\
(0.05)\end{array}$ \\
\hline Education & $\begin{array}{c}0.01 \\
(0.02)\end{array}$ & $\begin{array}{c}0.01 \\
(0.02)\end{array}$ & $\begin{array}{c}0.01 \\
(0.02)\end{array}$ & $\begin{array}{c}0.01 \\
(0.02)\end{array}$ \\
\hline
\end{tabular}


Table A2. (Continued.)

\begin{tabular}{|c|c|c|c|c|}
\hline & $\begin{array}{c}\text { Model 10: } \\
\text { including length of } \\
\text { stay }\end{array}$ & $\begin{array}{l}\text { Model 11: including } \\
\text { ethnic identity }\end{array}$ & $\begin{array}{l}\text { Model 12: including } \\
\text { discrimination }\end{array}$ & $\begin{array}{c}\text { Model 13: including all } \\
\text { immigrant-specific variables }\end{array}$ \\
\hline \multirow[t]{2}{*}{ Gender: male } & -0.00 & -0.00 & -0.00 & -0.00 \\
\hline & $(0.02)$ & $(0.02)$ & $(0.02)$ & $(0.02)$ \\
\hline \multirow[t]{2}{*}{ Political interest } & 0.04 & 0.04 & 0.04 & 0.04 \\
\hline & $(0.03)$ & $(0.03)$ & $(0.03)$ & $(0.03)$ \\
\hline \multirow[t]{2}{*}{ Constant } & $0.08^{\star \star}$ & $0.08^{\star \star}$ & $0.08^{\star \star}$ & $0.08^{\star \star}$ \\
\hline & $(0.03)$ & $(0.03)$ & $(0.03)$ & $(0.03)$ \\
\hline \multicolumn{5}{|c|}{ Candidate evaluations $\leftarrow$} \\
\hline \multirow{2}{*}{$\begin{array}{l}\text { MV candidate } \\
\text { evaluations }\end{array}$} & -0.03 & -0.03 & -0.03 & -0.03 \\
\hline & $(0.02)$ & $(0.02)$ & $(0.02)$ & $(0.02)$ \\
\hline \multirow[t]{2}{*}{ Party ID } & $0.27^{\star \star \star}$ & $0.27^{\star \star \star}$ & $0.27^{\star \star \star}$ & $0.27^{\star \star \star}$ \\
\hline & $(0.02)$ & $(0.02)$ & $(0.02)$ & $(0.02)$ \\
\hline \multirow[t]{2}{*}{ Constant } & $0.48^{\star \star \star}$ & $0.48^{\star \star \star}$ & $0.48^{\star \star \star}$ & $0.48^{\star \star \star}$ \\
\hline & $(0.01)$ & $(0.01)$ & $(0.01)$ & $(0.01)$ \\
\hline \multicolumn{5}{|l|}{ Issue orientations $\leftarrow$} \\
\hline \multirow[t]{2}{*}{ MV issues } & -0.01 & -0.01 & -0.01 & -0.01 \\
\hline & $(0.03)$ & $(0.03)$ & $(0.03)$ & $(0.03)$ \\
\hline \multirow[t]{2}{*}{ Party ID } & $0.37^{\star \star \star}$ & $0.37^{\star \star \star}$ & $0.37^{\star \star \star}$ & $0.37^{\star \star \star}$ \\
\hline & $(0.03)$ & $(0.03)$ & $(0.03)$ & $(0.03)$ \\
\hline \multirow[t]{2}{*}{ Constant } & $0.07^{\star \star \star}$ & $0.07^{\star \star \star}$ & $0.07^{\star \star \star}$ & $0.07^{\star \star \star}$ \\
\hline & $(0.01)$ & $(0.01)$ & $(0.01)$ & $(0.01)$ \\
\hline \multicolumn{5}{|l|}{ PTV $\leftarrow$} \\
\hline \multirow[t]{2}{*}{ MV PTV } & 0.11 & 0.11 & 0.11 & 0.11 \\
\hline & $(0.31)$ & $(0.31)$ & $(0.31)$ & $(0.31)$ \\
\hline \multirow[t]{2}{*}{ Party ID } & $2.11^{\star \star \star}$ & $2.11^{\star \star \star}$ & $2.11^{\star \star \star}$ & $2.11^{\star \star \star}$ \\
\hline & $(0.30)$ & $(0.30)$ & $(0.30)$ & $(0.30)$ \\
\hline \multirow[t]{2}{*}{ Candidates } & $3.54^{\star \star \star}$ & $3.54^{\star \star \star}$ & $3.54^{\star \star \star}$ & $3.54^{\star \star \star}$ \\
\hline & $(0.24)$ & $(0.24)$ & $(0.24)$ & $(0.24)$ \\
\hline \multirow[t]{2}{*}{ Issue orientations } & $2.04^{\star \star \star}$ & $2.04^{\star \star \star}$ & $2.04^{\star \star \star}$ & $2.04^{\star \star \star}$ \\
\hline & $(0.44)$ & $(0.44)$ & $(0.44)$ & $(0.44)$ \\
\hline \multirow{2}{*}{$\begin{array}{l}\text { Immigrant group: } \\
\text { Turkish }\end{array}$} & -0.09 & -0.09 & -0.09 & -0.09 \\
\hline & $(0.14)$ & $(0.14)$ & $(0.14)$ & $(0.14)$ \\
\hline \multirow[t]{2}{*}{ Constant } & $3.05^{\star \star \star}$ & $3.05^{\star \star \star}$ & $3.05^{\star \star \star}$ & $3.05^{\star \star \star}$ \\
\hline & $(0.31)$ & $(0.31)$ & $(0.31)$ & $(0.31)$ \\
\hline \multirow[t]{2}{*}{ Variance PTV } & $6.51^{\star \star \star}$ & $6.51^{\star \star \star}$ & $6.51^{\star \star \star}$ & $6.51^{\star \star \star}$ \\
\hline & $(0.23)$ & $(0.23)$ & $(0.23)$ & $(0.23)$ \\
\hline \multirow[t]{2}{*}{ Variance MV PTV } & 0.11 & 0.12 & 0.12 & 0.11 \\
\hline & $(0.01)$ & $(0.01)$ & $(0.01)$ & $(0.01)$ \\
\hline Variance party ID & $0.10^{\star \star \star}$ & $0.10^{\star \star \star}$ & $0.10^{\star \star \star}$ & $0.10^{\star \star \star}$ \\
\hline & $(0.01)$ & $(0.01)$ & $(0.01)$ & $(0.01)$ \\
\hline Variance MV party ID & 0.08 & 0.08 & 0.08 & 0.08 \\
\hline & $(0.01)$ & $(0.01)$ & $(0.01)$ & $(0.01)$ \\
\hline Variance candidates & 0.08 & 0.08 & 0.08 & 0.08 \\
\hline & $(0.01)$ & $(0.01)$ & $(0.01)$ & $(0.01)$ \\
\hline Variance MV & 0.11 & 0.12 & 0.12 & 0.11 \\
\hline & $(0.01)$ & $(0.01)$ & $(0.01)$ & $(0.01)$ \\
\hline Variance issues & $0.06^{\star \star \star}$ & $0.06^{\star \star \star}$ & $0.06^{\star \star \star}$ & $0.06^{\star \star \star}$ \\
\hline & $(0.00)$ & $(0.00)$ & $(0.00)$ & $(0.00)$ \\
\hline Variance MV issues & 0.14 & 0.14 & 0.14 & 0.14 \\
\hline & $(0.01)$ & $(0.01)$ & $(0.01)$ & $(0.01)$ \\
\hline Covariance & $0.01^{\star \star \star}$ & $0.01^{\star \star \star}$ & $0.01^{\star \star \star}$ & $0.01^{\star \star \star}$ \\
\hline & $(0.00)$ & $(0.00)$ & $(0.00)$ & $(0.00)$ \\
\hline $\mathrm{N}$ & 5,412 & 5,412 & 5,412 & 5,412 \\
\hline
\end{tabular}

Notes: Weighted and stacked data, MV = missing value, robust standard errors in parentheses, mean coefficients after multiple imputation analyses with $\mathrm{m}=5$; all continuous independent variables recoded to range from 0 to $1 .{ }^{\star \star \star} p<0.001 ;{ }^{\star \star} p<0.01 ;{ }^{\star} p<0.05$. 